\title{
Transfer Hydrogenation and Antiproliferative Activity of Tethered Half-Sandwich Organoruthenium Catalysts
}

Feng Chen, ${ }^{\dagger}$ Isolda Romero-Canelón, ${ }^{\dagger,}{ }^{\dagger}$ Joan J. Soldevila-Barreda, ${ }^{\dagger}$ Ji-Inn Song, ${ }^{\dagger}$ James P. C. Coverdale, $^{\dagger}$ Guy J. Clarkson, ${ }^{\dagger}$ Jana Kasparkova, ${ }^{\S(0)}$ Abraha Habtemariam, ${ }^{\dagger}$ Martin Wills, ${ }^{\dagger \oplus}$ Viktor Brabec, ${ }^{\S(0)}$ and Peter J. Sadler* ${ }^{*}+$ (1)

${ }^{\dagger}$ Department of Chemistry, University of Warwick, Gibbet Hill Road, Coventry CV4 7AL, U.K.

${ }^{\ddagger}$ School of Pharmacy, Institute of Clinical Sciences, University of Birmingham, Birmingham B15 2TT, U.K.

${ }^{\S}$ Institute of Biophysics, Academy of Sciences of the Czech Republic, Kralovopolska 135, CZ-61265 Brno, Czech Republic

\section{Supporting Information}

ABSTRACT: We report the synthesis and characterization of four neutral organometallic tethered complexes, $\left[\mathrm{Ru}\left(\eta^{6}-\mathrm{Ph}\left(\mathrm{CH}_{2}\right)_{3}\right.\right.$-ethylenediamine- $\mathrm{N}-\mathrm{R}) \mathrm{Cl}]$, where $\mathrm{R}=$ methanesulfonyl (Ms, 1), toluenesulfonyl (Ts, 2), 4-trifluoromethylbenzenesulfonyl (Tf, 3), and 4nitrobenzenesulfonyl $(\mathrm{Nb}, 4)$, including their X-ray crystal structures. These complexes exhibit moderate antiproliferative activity toward human ovarian, lung, hepatocellular, and breast cancer cell lines. Complex 2 in particular exhibits a low cross-resistance with cisplatin. The complexes show potent catalytic activity in the transfer hydrogenation of $\mathrm{NAD}^{+}$to $\mathrm{NADH}$ with formate as hydride donor in aqueous solution $(310 \mathrm{~K}, \mathrm{pH} 7)$. Substituents on the chelated ligand decreased the turnover frequency in the order $\mathrm{Nb}>\mathrm{Tf}>\mathrm{Ts}>$ Ms. An enhancement of antiproliferative activity (up to $22 \%$ ) was observed on coadministration with nontoxic concentrations of sodium formate $(0.5-2 \mathrm{mM})$. Complex 2 binds to nucleobase guanine (9EtG), but DNA appears not to be the target, as little binding to calf thymus DNA or bacterial plasmid DNA was observed. In addition, complex 2 reacts rapidly with glutathione (GSH), which might hamper transfer hydrogenation reactions in cells. Complex 2 induced a dose-dependent $\mathrm{G}_{1}$ cell cycle arrest after $24 \mathrm{~h}$ exposure in A2780 human ovarian cancer cells while promoting an increase in reactive oxygen species (ROS), which is likely to contribute to its antiproliferative activity.

\section{INTRODUCTION}

The clinical anticancer drug cisplatin arose from the serendipitous discovery of its biological anticancer activity by Rosenberg et al. about 50 years ago. ${ }^{1}$ Since then, anticancer complexes based on other platinum-group metals $\left(\mathrm{Ru}^{2-4} \mathrm{Rh}^{5-8} \mathrm{Os},{ }^{9-11} \mathrm{Ir}^{12,13}\right.$ and $\mathrm{Pd}^{14-17}$ ) have been studied. Ruthenium complexes have shown promising potential with relatively low toxicity and might provide alternatives to platinum drugs. These $\mathrm{Ru}$ complexes also have the potential to overcome the severe side effects and drug resistance which are problems with some platinum-based chemotherapeutics. $^{18,19}$ The two $\mathrm{Ru}^{\mathrm{III}}$ complexes NAMI-A and KP-1019 (Figure 1) have entered phase II clinical trials, the former as an antimetastatic agent. ${ }^{20-22}$ The mode of action of NAMI-A and KP-1019 in cancer cells is not yet understood, but the reduction of $\mathrm{Ru}^{\mathrm{III}}$ to $\mathrm{Ru}^{\mathrm{II}}$ is a plausible pathway for their activation. ${ }^{23,24}$ The $\mathrm{Ru}^{\mathrm{II}}$ complex $\left[\mathrm{Ru}\left(\eta^{6}-p\right.\right.$-cym $) \mathrm{Cl}_{2}$ (PTA)] ( $p$ cym = para-cymene, PTA $=1,3,5$-triaza-7phosphatricyclo[3.3.1.1]decane; RAPTA in Figure 1) also exhibits promising antimetastatic effects in vitro and in vivo ${ }^{25}$ and has antiangiogenic activity toward chicken chorioallantoic membranes with low dose-dependent antiproliferative activity. ${ }^{26}$ $\left[\left(\eta^{6}\right.\right.$-biph $) \mathrm{Ru}($ en $\left.) \mathrm{Cl}\right] \mathrm{PF}_{6}$ (biph = biphenyl, en = ethylenedi- amine; RM175 in Figure 1) is believed to target DNA and can bind to guanine bases accompanied by arene intercalation. It can also induce oxidation of bound glutathione (GSH), which can be displaced by guanine, providing a redox-mediated route to DNA binding. $^{27,28}$

Organometallic half-sandwich $\mathrm{Ru}^{\mathrm{II}}$ complexes also exhibit catalytic activity in transfer hydrogenation $(\mathrm{TH})$ reactions using a variety of reducing agents as a hydride source (e.g., $\mathrm{H}_{2}$, isopropyl alcohol, and sodium formate).$^{29-32}$ The Noyori-type $\mathrm{Ru}^{\mathrm{II}}$ complex $\left[\left(\eta^{6}-p\right.\right.$-cym $\left.) \mathrm{Ru}(\mathrm{TsDPEN}) \mathrm{Cl}\right](\mathrm{TsDPEN}=(R, R)-$ $\mathrm{N}$-( $p$-toluenesulfonyl)-1,2-diphenylethylenediamine $)$ is an efficient catalyst for the asymmetric transfer hydrogenation of ketones and amines with high yields and enantiomeric excesses using isopropyl alcohol or formic acid as hydride source (Figure 1). ${ }^{33,34}$ The sulfonyl $\mathrm{Ru}^{\mathrm{II}}$ complex $\left[\left(\eta^{6}\right.\right.$-arene $\left.) \mathrm{Ru}(\mathrm{TsEn}) \mathrm{Cl}\right]$ (TsEn = toluenesulfonylethylenediamine) is a more water soluble catalyst and, under biologically relevant conditions, can reduce the coenzyme nicotinamide adenine dinucleotide $\left(\mathrm{NAD}^{+}\right)$in vitro and in cells using nontoxic doses of sodium

Received: March 5, 2018

Published: April 23, 2018 


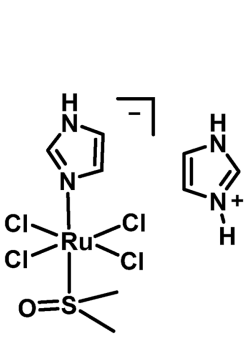

NAMI-A

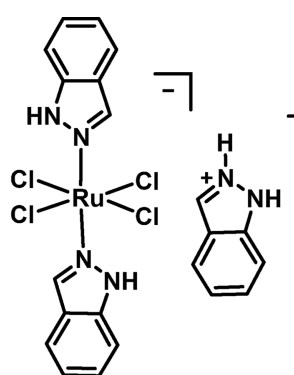

KP-1019

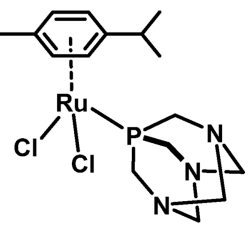

RAPTA

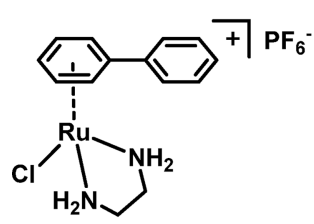

RM175

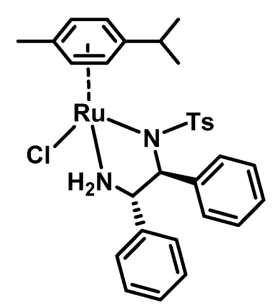

[(p-cym)Ru(TsDPEN)CI]

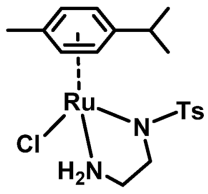

JS2
Figure 1. Organometallic half-sandwich $\mathrm{Ru}^{\mathrm{II}}$ and $\mathrm{Ru}^{\mathrm{III}}$ (NAMI-A and KP-1019) anticancer agents and catalytic transfer hydrogenation catalysts.

formate as hydride donor (JS2 in Figure 1). ${ }^{35-37}$ Mammalian cells can often tolerate millimolar levels of formate without observed toxicity. 35,37

Tethered $\mathrm{Ru}^{\mathrm{II}}$ half-sandwich compounds in which the $\eta^{6}$-arene ring and a diamine ligand are connected through a three (or four)-atom chain have a "locked" arene ring, providing control over the spatial positions of the substituents on the ethylenediamine ligands, and have enhanced stability. ${ }^{38,39}$ Wills et al. have reported a series of tethered $\mathrm{Ru}^{\mathrm{II}} \eta^{6}$-arene complexes and used them as efficient catalysts in the transfer hydrogenation reactions of ketones and amines. ${ }^{40,41}$ However, there have been few investigations on the antiproliferative activity of tethered $\mathrm{Ru}^{\mathrm{II}}$ complexes. Recently, chiral tethered $\mathrm{Ru}^{\mathrm{II}}$ complexes (two enantiomers) were synthesized and found to have potent antiproliferative activity toward a panel of NCI-60 cancer cell lines $\left(\mathrm{IC}_{50}\right.$ against $\mathrm{A} 2780$ ovarian cancer cells as low as $1.1 \mu \mathrm{M}$; Figure 2). Interestingly, their potency increased by up to $25 \%$ upon coincubation of the cancer cells with formate. ${ }^{42}$

Here we have synthesized and characterized the water-soluble tethered $\mathrm{Ru}^{\mathrm{II}}$ complexes $\left[\mathrm{Ru}\left(\eta^{6}-\mathrm{Ph}\left(\mathrm{CH}_{2}\right)_{3}\right.\right.$-ethylenediamine- $N$ $\mathrm{R}) \mathrm{Cl}$ ], where $\mathrm{R}=$ methanesulfonyl ( $\mathrm{Ms}, \mathbf{1})$, toluenesulfonyl (Ts, 2), ${ }^{43}$ 4-trifluoromethylbenzenesulfonyl (Tf, 3), or 4-nitrobenzenesulfonyl $(\mathrm{Nb}, 4)$, including determination of their $\mathrm{X}$ -

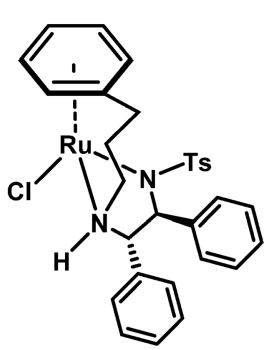

$(S, S)$-Tethered-Ru-TsDPEN

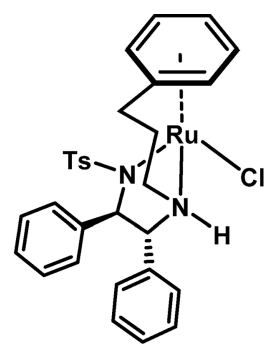

$(R, R)$-Tethered-Ru-TsDPEN
Figure 2. Enantiomers of chiral tethered $\mathrm{Ru}^{\mathrm{II}}$ TsDPEN complexes. ray crystal structures, and investigated their catalytic $\mathrm{TH}$ reduction of $\mathrm{NAD}^{+}$to $\mathrm{NADH}$ using sodium formate as a hydride source under biologically relevant conditions. The interaction of complex 2 with the abundant intracellular tripeptide $\gamma$-L-Glu-LCys-Gly (GSH) and the effect of GSH on catalytic TH reduction of $\mathrm{NAD}^{+}$were also studied. We also investigated the effect of nontoxic concentrations of formate on the antiproliferative activity of these complexes in several human cancer cell lines, the induction of reactive oxygen species (ROS), and changes in integrity of their cell membranes.

\section{RESULTS}

Synthesis and Characterization. The four neutral tethered $\mathrm{Ru}^{\mathrm{II}}$ complexes $\left[\mathrm{Ru}\left(\eta^{6}-\mathrm{Ph}\left(\mathrm{CH}_{2}\right)_{3}\right.\right.$-ethylenediamine- $\mathrm{N}$ - $\left.\left.\mathrm{R}\right) \mathrm{Cl}\right]$, where $\mathrm{R}=\mathrm{Ms}$ (1), Ts (2), Tf (3), and $\mathrm{Nb}$ (4), were synthesized following a literature method for related complexes (Scheme 1). They were characterized by elemental analysis (CHN), highresolution mass spectrometry, and $\operatorname{NMR}\left({ }^{1} \mathrm{H},{ }^{13} \mathrm{C}\right.$, and $\left.{ }^{19} \mathrm{~F}\right)$ spectroscopy (Figures $\mathrm{S} 1-\mathrm{S} 9$ in the Supporting Information).

Crystals of complexes 1-4 suitable for X-ray diffraction were obtained from a slow diffusion of diethyl ether into methanol solutions of the complexes at ambient temperature. The complexes adopt the expected pseudo-tetrahedral geometry with $\eta^{6}$-phenyl ring occupying three $\mathrm{Ru}$ coordination sites, together with nitrogen atoms of the diamine ligand (bond lengths $2.11-2.15 \AA$ ) and a monodentate chloride; ethylenediamine ligands are deprotonated and bound as monoanionic bidentate ligands. Generally, the $\mathrm{Ru}-\mathrm{N}(\mathrm{H})$ bond distance (range 2.140-2.149 $\AA$ ) is slightly longer than that of $\mathrm{Ru}-\mathrm{N}\left({ }^{-}\right.$) (2.112-2.121 $\AA$ ). The $\eta^{6}$-phenyl ring and ethylenediamine are linked by a three-carbon tether chain. The structures are shown in Figure 3. Selected bond lengths $(\AA)$ and bond angles (deg) are given in Table 1 and X-ray crystallographic data in Tables S1-S5.

$\mathrm{p} K_{\mathrm{a}}$ * Determination and Interaction with Guanine. The $\mathrm{p} K_{\mathrm{a}}^{*}$ value of the aqua adduct $2 \mathrm{a}$ (from complex 2 ) in MeOD$d_{4} / \mathrm{D}_{2} \mathrm{O}\left(1 / 9, \mathrm{v} / \mathrm{v}\right.$ ) was determined by ${ }^{1} \mathrm{H} \mathrm{NMR}$ at $310 \mathrm{~K}$ (Figure $\mathrm{S} 10 \mathrm{~A}$ in the Supporting Information) by titration over the $\mathrm{pH}^{*}$ (meter reading) range from 2 to 12 and plots of the chemical shift of a tosyl proton as a function of $\mathrm{pH}^{*}$ fitted to the HendersonHasselbalch equation. The $\mathrm{p} K_{\mathrm{a}}^{*}$ value of aqua complex $2 \mathrm{a}$ was found to be $9.52 \pm 0.03$; a second $\mathrm{p} K_{\mathrm{a}}^{*}$ value of $<2$ was too low to be determined.

The interaction of complex 2 with the DNA nucleobase model 9-ethylguanine (9-EtG; Figure S10B in the Supporting Information) was studied by ${ }^{1} \mathrm{H}$ NMR spectroscopy. Complex $2\left(2 \mathrm{mM}\right.$ in $\left.\mathrm{MeOD}-d_{4} / \mathrm{D}_{2} \mathrm{O}, 1 / 9(\mathrm{v} / \mathrm{v})\right)$ reacted rapidly with 9EtG $\left(1 \mathrm{mM}\right.$ in $\mathrm{D}_{2} \mathrm{O}$, within $\left.10 \mathrm{~min}\right)$ at $310 \mathrm{~K}$. The adduct 2-9EtG gave rise to a new set of $\eta^{6}$-arene peaks (Figure S10B in the Supporting Information), with up to $90 \%$ yield of 2-9-EtG when a 1.5 mol equiv 9-EtG solution was added.

A preliminary ${ }^{1} \mathrm{H}$ NMR study indicated that histidine can also displace the chloride ligand on $\mathbf{2}$ and form a stable adduct (Figure S10C in the Supporting Information), as might be expected, since, like guanine, it also contains an imidazole ring.

Transfer Hydrogenation Reactions. Catalytic transfer hydrogenation reactions of complexes 1-4 and sodium formate as hydride donor for conversion of nicotinamide adenine dinucleotide $\left(\mathrm{NAD}^{+}\right)$to $\mathrm{NADH}$ were studied in aqueous media by UV-visible spectroscopy by following the absorbance at $340 \mathrm{~nm}$ for $\mathrm{NADH}$ and by ${ }^{1} \mathrm{H}$ NMR spectroscopy (20\% DMSO- $d_{6}$ in $\mathrm{D}_{2} \mathrm{O}$ ) by monitoring peaks corresponding to $1,4-$ $\mathrm{NADH}$. The reactions were performed in the mixed solvent DMSO $-d_{6} / \mathrm{D}_{2} \mathrm{O}(1 / 4, \mathrm{v} / \mathrm{v})$ to ensure the solubility of these 
Scheme 1. Synthesis Route for Tethered $\mathrm{Ru}^{\mathrm{II}}$ Complexes $1-4^{a}$

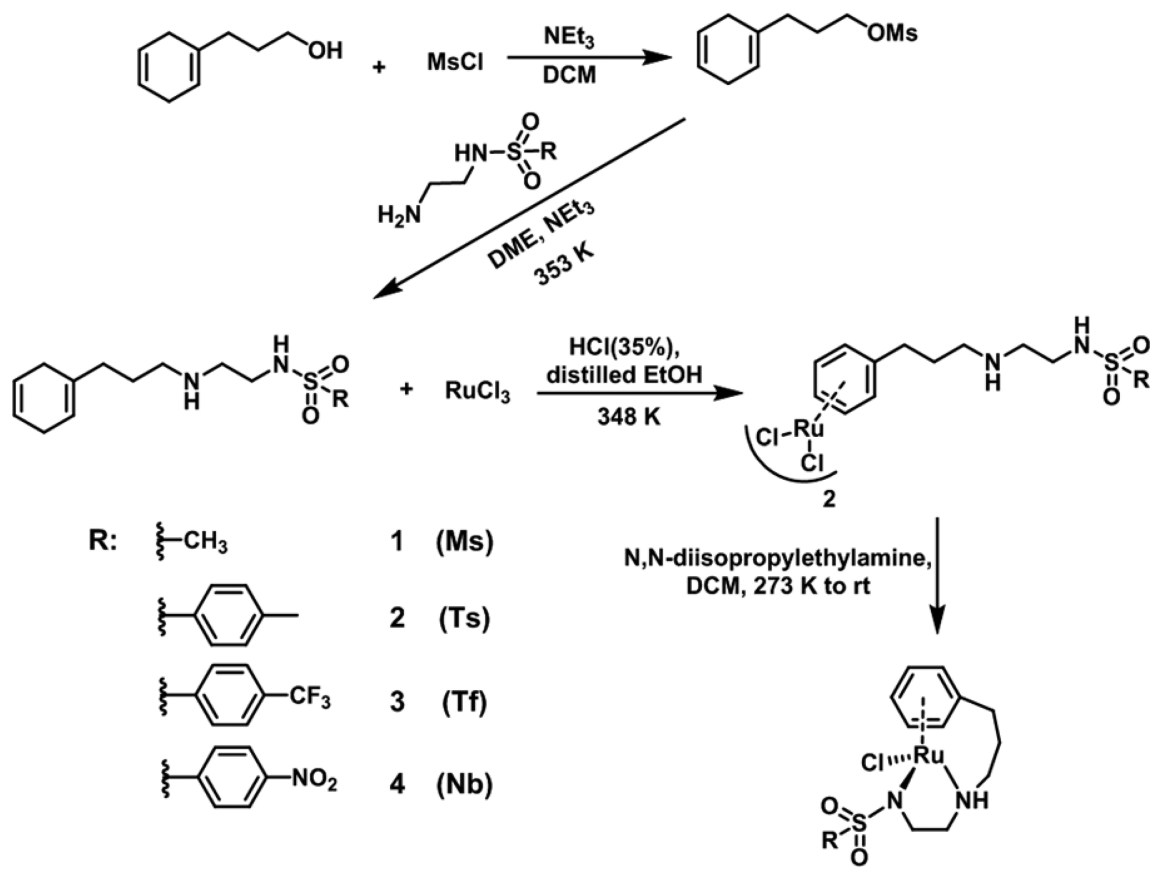

${ }^{a} \mathrm{DME}=1,2$-dimethoxyethane.

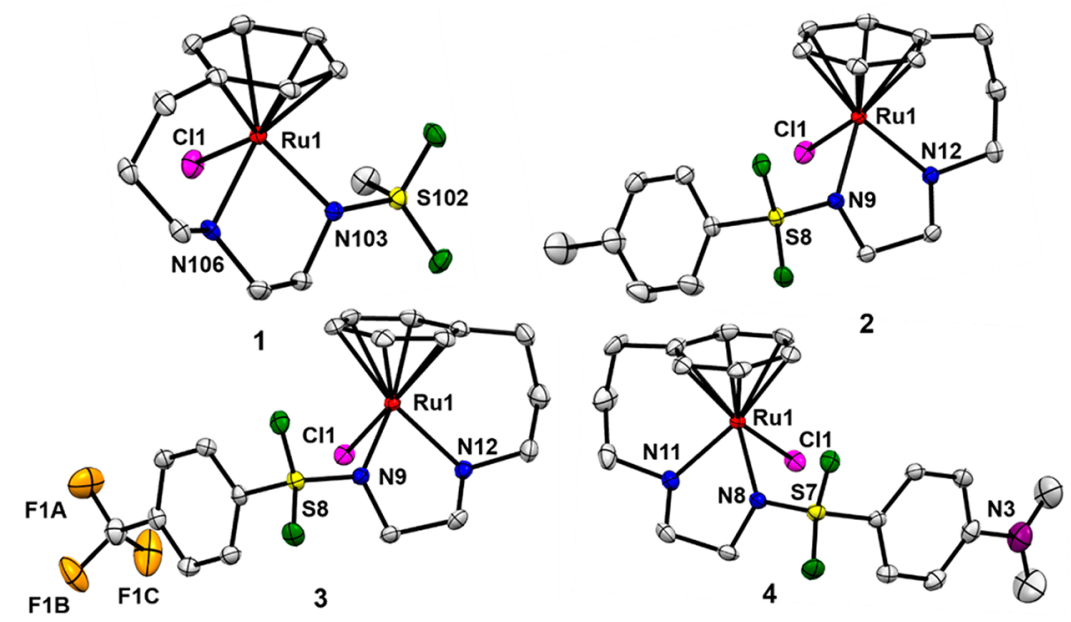

Figure 3. ORTEP diagrams for $\mathrm{Ru}^{\mathrm{II}}$ complexes $1-4$. Thermal ellipsoids are shown at the $50 \%$ probability level. All hydrogen atoms have been omitted for clarity.

Table 1. Selected Bond Lengths (§) and Angles (deg) for Complexes 1-4

\begin{tabular}{lllll} 
& \multicolumn{1}{c}{$\mathbf{1}$} & \multicolumn{1}{c}{$\mathbf{2}$} & \multicolumn{1}{c}{$\mathbf{3}$} & \multicolumn{1}{c}{$\mathbf{4}$} \\
$\mathrm{Ru} 1-\mathrm{N}\left({ }^{-}\right)^{a}$ & $2.121(2)$ & $2.1181(14)$ & $2.1202(16)$ & $2.1124(18)$ \\
$\mathrm{Ru} 1-\mathrm{N}(\mathrm{H})^{b}$ & $2.146(2)$ & $2.1490(14)$ & $2.1485(16)$ & $2.140(2)$ \\
$\mathrm{Ru} 1-\mathrm{Cl} 1$ & $2.4174(6)$ & $2.4234(4)$ & $2.4243(4)$ & $2.4142(6)$ \\
Ru1-arene (centroid) & 1.654 & 1.657 & 1.658 & 1.653 \\
$\mathrm{~N}\left({ }^{-}\right)-\mathrm{Ru} 1-\mathrm{N}(\mathrm{H})$ & $78.77(8)$ & $78.87(5)$ & $78.87(6)$ & $78.54(7)$ \\
$\mathrm{N}\left({ }^{-}\right)-\mathrm{Ru} 1-\mathrm{Cl1}$ & $88.17(6)$ & $88.29(4)$ & $87.33(4)$ & $87.24(5)$ \\
$\mathrm{N}(\mathrm{H})-\mathrm{Ru} 1-\mathrm{Cl} 1$ & $83.20(6)$ & $83.02(4)$ & $83.56(5)$ & $83.43(6)$
\end{tabular}

${ }^{a} \mathrm{~N}\left({ }^{-}\right)$corresponds to N103(1), N9(2,3), and N8(4). ${ }^{b} \mathrm{~N}(\mathrm{H})$ corresponds to N106(1), N12(2,3), and N11(4).

complexes, although it was found earlier that the rates of such $\mathrm{TH}$ reactions are enhanced in methanol, which like DMSO is a solvent of lower polarity in comparison to water. ${ }^{36}$
All of the tethered $\mathrm{Ru}^{\mathrm{II}}$ complexes exhibited potent catalytic activity, with TOFs by UV-vis and NMR spectroscopy in the ranges $3.7-8.9$ and $5.8-9.9 \mathrm{~h}^{-1}$, respectively (Table 2), following the order $1<2<3<4$, suggesting that more strongly electron 
withdrawing groups on the ethylenediamine ligand facilitate hydride transfer between formate and $\mathrm{NAD}^{+}$.

Table 2. TOFs $\left(\mathrm{h}^{-1}\right)$ for Transfer Hydrogenation Reactions of $\mathrm{NAD}^{+}$to NADH using Complexes $1-4$ as Catalysts and Formate as Hydride Donor

$\begin{array}{cccc}\text { complex } & \text { R } & \text { TOF (NMR) } & \text { TOF (UV-vis) } \\ \mathbf{1} & \text { Ms } & 3.79 \pm 0.05 & 5.8 \pm 0.2 \\ \mathbf{2} & \mathrm{Ts} & 4.7 \pm 0.1 & 8.3 \pm 0.1 \\ \mathbf{3} & \mathrm{Tf} & 8.9 \pm 0.3 & 8.69 \pm 0.07 \\ \mathbf{4} & \mathrm{Nb} & 8.5 \pm 0.2 & 9.9 \pm 0.2\end{array}$

The $\mathrm{TH}$ reactions were also studied by NMR in solutions with a higher DMSO $-d_{6} / \mathrm{D}_{2} \mathrm{O}$ ratio. Above $20 \%$ DMSO, the rate increased markedly (Figure S11 in the Supporting Information), and that with $80 \%$ DMSO was too fast to follow by NMR.

Interaction with Glutathione (GSH). The reaction of complex $2\left(\left[\mathrm{Ru}\left(\eta^{6}-\mathrm{Ph}\left(\mathrm{CH}_{2}\right)_{3}\right.\right.\right.$-ethylenediamine- $\left.\left.\left.\mathrm{N}-\mathrm{Ts}\right) \mathrm{Cl}\right]\right)$ with GSH was initially monitored by ${ }^{1} \mathrm{H}$ NMR. As shown in Figure S2 in the Supporting Information, the low-field $\eta^{6}$-phenyl peaks of complex 2 decreased gradually, and a new set of triplets ( $\mathrm{H} 1^{\prime}$ and $\mathrm{H} 2^{\prime}$ ) emerged when 0.2 and $0.5 \mathrm{~mol}$ equiv of GSH were added. The low-field resonances of the tosyl protons of complex 2 ( $\mathrm{H} 1$ and $\mathrm{H} 2$ ) disappeared and a new set of peaks $\left(\mathrm{H} 1^{\prime}-\mathrm{H} 7^{\prime}\right)$ appeared when $1 \mathrm{~mol}$ equiv or more of GSH was added (Figure S12 in the Supporting Information). The reaction was confirmed by LC-MS, which revealed that the 2-SG adduct was formed rapidly when 2 was mixed with GSH (Figure S13 in the Supporting Information). The eluents are shown in Figure S14 in the Supporting Information.

Next, the time dependence of the reaction of complex 2 with GSH was studied under similar conditions: $2 \mathrm{mM} 2$ in MeOD$d_{4} / \mathrm{D}_{2} \mathrm{O}(2 / 8 \mathrm{v} / \mathrm{v})$ with $20 \mathrm{mM} \mathrm{GSH}$, monitored by ${ }^{1} \mathrm{H}$ NMR spectroscopy from $5 \mathrm{~min}$ to $24 \mathrm{~h}$ (Figure 4). As in the above experiments, a new set of low-field resonances appeared immediately $\left(\mathrm{H}^{\prime}-\mathrm{H} 6^{\prime}\right)$ in the presence of excess GSH (10 mol equiv), but with time, the low-field resonances $\mathrm{H}^{\prime}-\mathrm{H}^{\prime}{ }^{\prime}$ decreased gradually and disappeared after $24 \mathrm{~h}$ (Figure 4); meanwhile, another two new sets of peaks slowly appeared. The 2D NMR (COSY) spectrum suggested that the 2-SG adduct degraded with time to release the neutral free ligand $\eta^{6}$ $\mathrm{Ph}\left(\mathrm{CH}_{2}\right)_{3}$-ethylenediamine- $\mathrm{N}(\mathrm{H})$-Ts (assigned to one of the two sets of low-field peaks, Figure S15 in the Supporting Information) with up to $70 \%$ of decomposition observed within $5 \mathrm{~h}$ incubation at $310 \mathrm{~K}$, as shown in Figure S16 in the Supporting Information. Such liberation of free ligand was also detected by LC-MS at $333.21 \mathrm{~m} / z$ (calculated [ligand $+\mathrm{H}]^{+} \mathrm{m} / z$ 333.16, Figure S13 in the Supporting Information). Complex 1 ( $2 \mathrm{mM}$ in $\left.\mathrm{MeOD}-d_{4} / \mathrm{D}_{2} \mathrm{O}(1 / 4 \mathrm{v} / \mathrm{v}), \mathrm{pH}^{*} 7\right)$ showed a behavior in reactions with GSH ( 10 mol equiv) similar to that of complex 2 . 1-SG adduct formed rapidly but decomposed after $24 \mathrm{~h}$ incubation at $310 \mathrm{~K}$. Complexes 3 and 4 (2 $\mathrm{mM}$ in DMSO- $d_{6}$ / $\left.\mathrm{D}_{2} \mathrm{O}(1 / 4 \mathrm{v} / \mathrm{v})\right)$ also reacted with $\mathrm{GSH}$, but the $\mathrm{SG}$ adduct
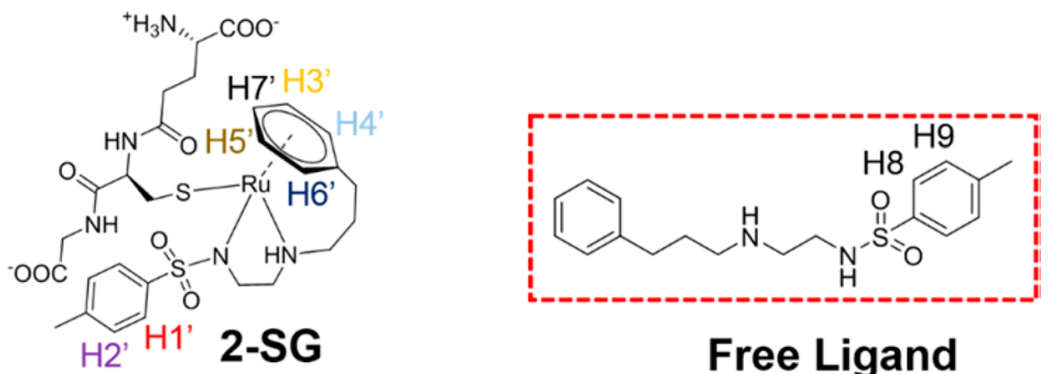

Free Ligand
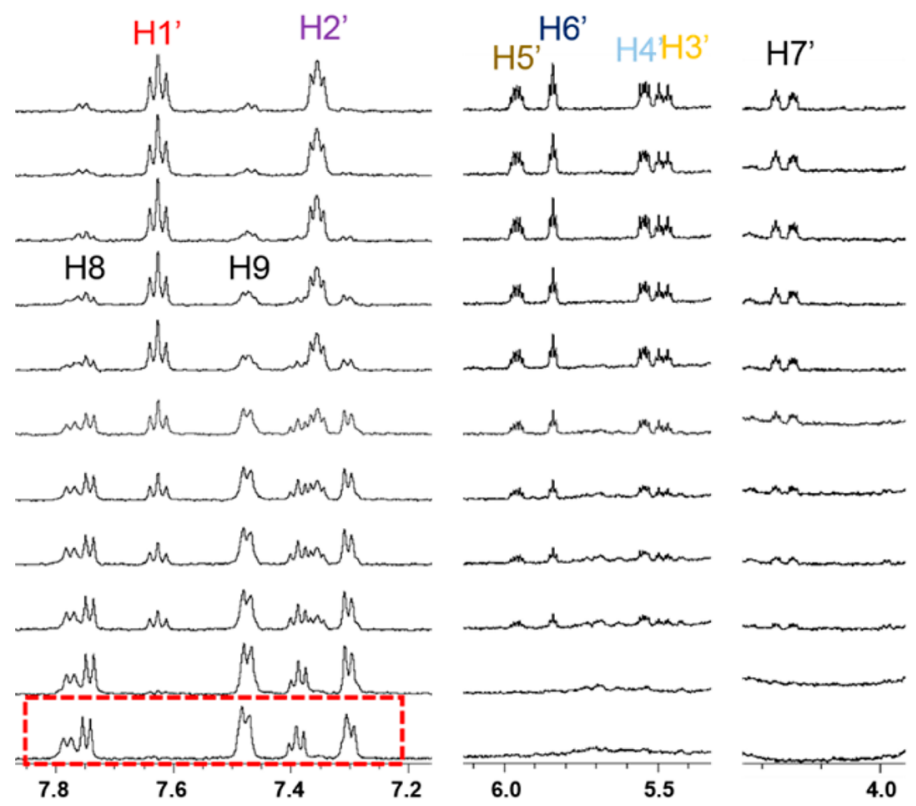

$5 \mathrm{~min}$

$10 \mathrm{~min}$

$20 \mathrm{~min}$

$40 \mathrm{~min}$

$60 \mathrm{~min}$

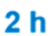

$3 \mathrm{~h}$

$4 \mathrm{~h}$

5 h

$18 \mathrm{~h}$

Figure 4. Dependence on time of the interaction of complex $2\left(2 \mathrm{mM}\right.$ in MeOD- $\left.d_{4} / \mathrm{H}_{2} \mathrm{O}(2 / 8 \mathrm{v} / \mathrm{v})\right)$ with GSH $(20 \mathrm{mM}$, in D $2 \mathrm{O}$, pH* adjusted to $7.2 \pm$ $0.1)$, monitored by ${ }^{1} \mathrm{H} \mathrm{NMR}(600 \mathrm{MHz})$ at $310 \mathrm{~K}$. The two sets of peaks for $\mathrm{H}^{\prime}{ }^{\prime}-\mathrm{H} 7^{\prime}$ can be assigned to diastereomers; free ligand resonances in the low-field region are shown in the dashed red box. 
Table 3. In Vitro Anticancer Activity of Complexes 1-4 Against Various Cell Lines

\begin{tabular}{|c|c|c|c|c|c|c|c|}
\hline \multirow[b]{2}{*}{ complex } & \multicolumn{7}{|c|}{ cell line ${ }^{a} \mathrm{IC}_{50}(\mu \mathrm{M})$} \\
\hline & $\mathrm{A} 2780$ & $\mathrm{~A} 2780 \mathrm{Cis}$ & A549 & HEPG2 & MCF 7 & MRC 5 & $\mathrm{RI}^{b}$ \\
\hline 1 & $23 \pm 1$ & $>50$ & $33 \pm 1$ & $27.8 \pm 0.1$ & $28.9 \pm 0.9$ & $31 \pm 1$ & $>2$ \\
\hline 2 & $7.3 \pm 0.4$ & $15 \pm 1$ & $37.6 \pm 0.6$ & $26 \pm 4$ & $33 \pm 2$ & $38 \pm 1$ & 2 \\
\hline 3 & $>50$ & $>50$ & $31 \pm 2$ & $>50$ & $24 \pm 3$ & $28 \pm 3$ & n.d. \\
\hline 4 & $16.0 \pm 0.3$ & $>50$ & $30 \pm 1$ & $23 \pm 4$ & $9.9 \pm 0.5$ & $26 \pm 1$ & $>3$ \\
\hline CDDP & $1.20 \pm 0.02$ & $13.4 \pm 0.3$ & $3.1 \pm 0.1$ & $5.7 \pm 0.9$ & $7.3 \pm 0.2$ & $12.8 \pm 0.3$ & 11 \\
\hline
\end{tabular}

${ }^{a}$ Data are shown as means \pm standard deviations (STD), from duplicates of triplicates; cell viability was assessed after $24 \mathrm{~h}$ drug exposure and $72 \mathrm{~h}$ recovery in drug-free medium. Human cell lines: A2780, ovarian cancer; A2780Cis, cisplatin-resistant ovarian cancer; A549, lung cancer; HEPG2, hepatocellular cancer; MCF7, breast cancer; MRC5, normal lung fibroblasts. ${ }^{b} \mathrm{RI}$ denotes the resistance index between A2780 ovarian cancer cells and its resistant derivative $\mathrm{A} 2780 \mathrm{Cis}$. n.d. = not determined.

appeared to be stable under these conditions, since the ${ }^{1} \mathrm{H}$ NMR spectra appeared to be unchanged after $24 \mathrm{~h}$ incubation at $310 \mathrm{~K}$ (data not shown). Complexes 3 and 4 both have electronwithdrawing groups on the phenyl ring of the sulfonamide substituent.

Reduction of $\mathrm{NAD}^{+}$by TH in the Presence of GSH. Due to the thiophilic nature and instability of complex 2 in the presence of GSH, the influence of GSH on the conversion of $\mathrm{NAD}^{+}$to $\mathrm{NADH}$ by $\mathrm{TH}$ from complex 2 with formate as the hydride source was investigated. ${ }^{1} \mathrm{H}$ NMR spectra (MeOD- $d_{4} /$ $\left.\mathrm{D}_{2} \mathrm{O}(2 / 8 \mathrm{v} / \mathrm{v})\right)$, at $\mathrm{pH}^{*} 7.2$ and $310 \mathrm{~K}$ with complex $2, \mathrm{NAD}^{+}$, $\mathrm{GSH}$, and sodium formate in the mole ratio of $1 / 4 / X / 25$ (where $X=0.5,1,2$ and 5 , respectively) were recorded every $5 \mathrm{~min}$. The turnover frequency of $\mathrm{NAD}^{+}$to $\mathrm{NADH}$ decreased slightly in the presence of $0.5 \mathrm{~mol}$ equiv of GSH (TOF $4.27 \pm 0.05 \mathrm{~h}^{-1}$ ); however, the TOF decreased dramatically to $1.35 \mathrm{~h}^{-1}$ when 1.0 mol equiv of GSH was present. The hydride transfer reaction completely stopped when excess GSH was added ( 2 or $5 \mathrm{~mol}$ equiv).

Antiproliferative Activity. The antiproliferative activity of tethered $\mathrm{Ru}^{\mathrm{II}}$ complexes $\mathbf{1 - 4}$ against human ovarian (A2780), lung (A549), hepatocellular (HEPG2), breast (MCF7), and cisplatin-resistant ovarian (A2780Cis) cancer cell lines and normal human lung fibroblast cells (MRC5) was determined (Table 3) and compared to that of the clinical drug cisplatin (CDDP). Complexes 1-4 exhibited good to moderate anticancer activity against all of these cancer cell lines, with $\mathrm{IC}_{50}$ values in the range of 7.3->50 $\mu \mathrm{M}$. Complex 2 displayed good anticancer activity against A2780 and cisplatin-resistant A2780 cancer cells, with $\mathrm{IC}_{50}$ values of 7.3 and $15 \mu \mathrm{M}$, respectively. Remarkably, this complex exhibits a resistance index (RI) of only 2 in comparison to 11 for cisplatin. The RI is the ratio of the activity $\left(\mathrm{IC}_{50}\right)$ toward the resistant cell line in comparison to the parental line and gives an indication of the capacity of a complex to overcome platinum resistance. Furthermore, complex 4 exhibited anticancer activity against MCF7 cancer cells similar to that of cisplatin, with an $\mathrm{IC}_{50}$ value of $9.9 \mu \mathrm{M}$. The antiproliferative activity in A549 lung and HEPG2 hepatocellular cancer cells has minimal variation among complexes 1-4, with all $\mathrm{IC}_{50}$ values averaging 32 and $25 \mu \mathrm{M}$, respectively. Corresponding values for the normal fibroblast cell line MRC5 are given in Table 3.

Cellular Accumulation of $\mathrm{Ru}$. Cellular $\mathrm{Ru}$ accumulation from administration of the most promising complexes 2 and $\mathbf{4}$ in A2780 human ovarian cancer cells and A2780Cis cells was determined. Complex 4 showed a higher cellular $\mathrm{Ru}$ accumulation in comparison to complex 2 in both A2780 and A2780Cis (Figure 5). The cellular Ru contents for complex 4 were $150 \pm 38$ ng per million A2780 cells and $241 \pm 10$ ng per million A2780Cis

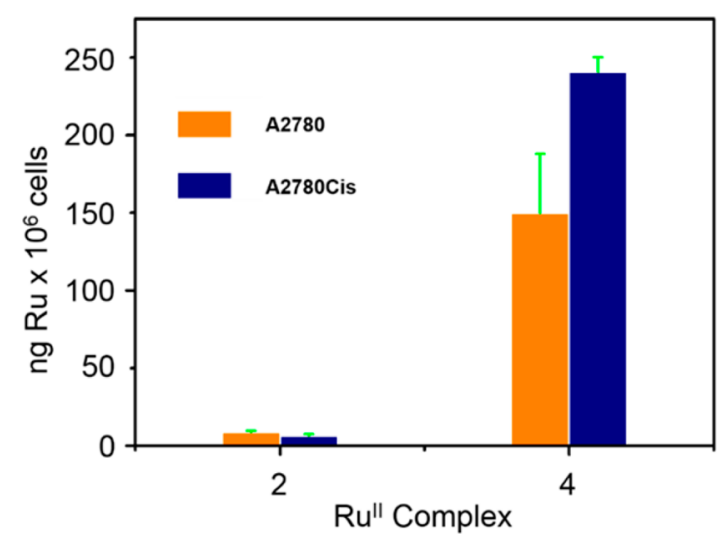

Figure 5. Cellular $\mathrm{Ru}$ accumulation in A2780 and A2780Cis ovarian cancer cells exposed to equipotent $\mathrm{IC}_{50}$ concentrations of complexes 2 and 4.

cells, while the cellular $\mathrm{Ru}$ content from complex 2 was much lower: $8.8 \pm 0.9$ and $7 \pm 1 \mathrm{ng}$ per million cells, respectively.

Cell Cycle Arrest. Since complex $2\left[\mathrm{Ru}\left(\eta^{6}-\mathrm{Ph}\left(\mathrm{CH}_{2}\right)_{3^{-}}\right.\right.$ ethylenediamine- $\mathrm{N}-\mathrm{Ts}) \mathrm{Cl}]$ binds to the nucleobase guanine (9EtG), it was possible that DNA might be a target for anticancer activity. In order to investigate this, the effects on the cell cycle of A2780 cells exposed to complex 2 at $\mathrm{IC}_{50}$ and $2 \times \mathrm{IC}_{50}$ concentrations for $24 \mathrm{~h}$ were studied, using propidium iodide staining, and measured using flow cytometry (Figure 6). In comparison to negative control populations, a statistically significant increase of the cell population in the $G_{1}$ phase was

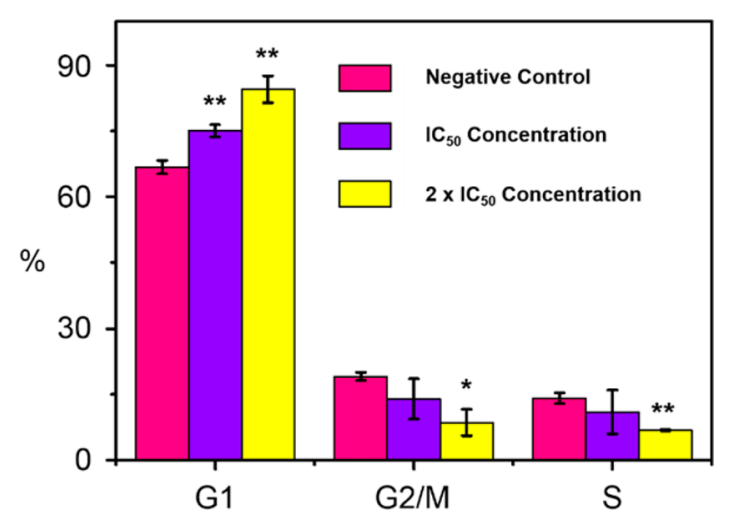

Figure 6. Cell cycle arrest analysis of A2780 human ovarian cancer cells after $24 \mathrm{~h}$ of exposure to complex 2 at $310 \mathrm{~K}$ at $\mathrm{IC}_{50}$ and $2 \times \mathrm{IC}_{50}$ concentrations. Cell staining for flow cytometry was carried out using PI/RNase. $p$ Values were calculated after a $t$-test against the negative control data: $* p<0.05, * * p<0.01$. 
observed, with percentages increasing to $75 \pm 1 \%$ at $\mathrm{IC}_{50}$ concentration and $85 \pm 3 \%$ population at $2 \times \mathrm{IC}_{50}$ concentration. This evidence of $G_{1}$ arrest with lack of an accumulation of cells in the $S$ phase might suggest that DNA is not a major target and that complex 2 could have a cytostatic effect on ovarian cancer cells. Nonetheless, studies of the interaction of complex 2 with DNA were carried out to investigate further (vide infra).

ROS Induction in A2780 Human Ovarian Cancer Cells. The level of reactive oxygen species (ROS) in A2780 human ovarian cancer cells induced by exposure to complex 2 was determined at $\mathrm{IC}_{50}$ concentration by flow cytometry fluorescence analysis (Figure 7). The total level of oxidative stress, including
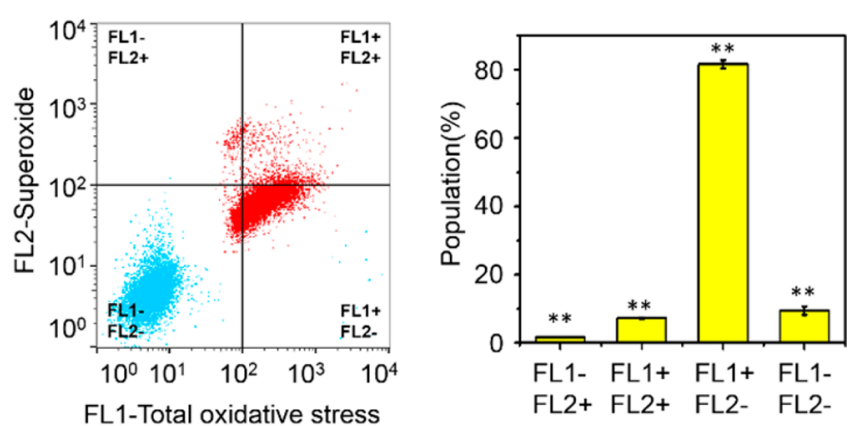

Figure 7. ROS induction in A2780 cancer cells exposed to complex 2. The FL1 channel detects total oxidative stress, and the FL2 channel detects superoxide production. Complex 2 is shown in red and negative control in blue. $p$ Values were calculated after a $t$-test against the negative control data: $* p<0.05, * * p<0.01$.

$\mathrm{H}_{2} \mathrm{O}_{2}$, peroxy and hydroxyl radical, peroxynitrite, $\mathrm{NO}$, and superoxide production, was monitored using the green channel FL1 and orange channel FL2, respectively. Increased ROS levels were detected in the majority of the population of A2780 cells, with up to $82 \%$ of cells exhibiting high fluorescence in the FL1green channel. There is only a minimal increase in the level of cellular superoxide (Table S6 in the Supporting Information).

Cell Membrane Integrity. We further investigated the effect of complex 2 on the cellular membrane integrity of A2780 ovarian cancer cells using flow cytometry analysis of cells exposed for $24 \mathrm{~h}$ to the ruthenium complex and stained in the dark with propidium iodide. This experiment did not include fixation of the cells prior to staining. The results show that there are no induced changes in the membrane integrity of cancer cells, as there are no statistical differences between the drug-exposed and negative control cells (Table S7 in the Supporting Information).

Calf Thymus DNA and Bacterial Plasmid DNA. The interaction of complex 2 ( $\left[\mathrm{Ru}\left(\eta^{6}-\mathrm{Ph}\left(\mathrm{CH}_{2}\right)_{3}\right.\right.$-ethylenediamine$\mathrm{N}-\mathrm{Ts}$ )Cl]) with double-helical calf thymus DNA (ct-DNA) and bacterial plasmid DNA was studied and compared to that of nontethered $\left[\left(\eta^{6}-p\right.\right.$-cym $\left.) \mathrm{Ru}(\mathrm{TsEn}) \mathrm{Cl}\right]$ (JS2 in Figure 1$){ }^{37}$ Double-helical ct-DNA at a concentration of $32 \mu \mathrm{g} \mathrm{mL}{ }^{-1}$ was incubated with JS2 or complex 2 at $r_{\mathrm{i}}$ values of 0.1 and 0.5 in 10 $\mathrm{mM} \mathrm{NaClO}{ }_{4}$ at $310 \mathrm{~K}\left(r_{\mathrm{i}}=\right.$ the molar ratio of free ruthenium complex to nucleotide phosphates at the onset of incubation with DNA). The reaction was terminated after $24 \mathrm{~h}$ of incubation, and samples were exhaustively dialyzed against water. The ruthenium content in these samples was determined by flameless atomic absorption spectrometry (FAAS) and the concentration of DNA by absorption spectrophotometry. No detectable amount of ruthenium was found in samples of DNA treated with JS2 or complex 2, even at very high $r_{\mathrm{i}}$. Therefore, these compounds do not bind strongly to high-molecular-mass DNA under the experimental conditions used.

In further experiments, solutions containing plasmid DNA pBR322 $\left(28 \mu \mathrm{g} \mathrm{mL}^{-1}\right)$ and complex JS2 or complex 2 in various molar ratios $\left(r_{\mathrm{i}}=0.05-1\right)$ were incubated in $0.01 \mathrm{M} \mathrm{NaClO}_{4}$ at $310 \mathrm{~K}$ for $24 \mathrm{~h}$ in the dark. Subsequently the samples were directly mixed with the loading buffer and loaded onto a $1 \%$ agarose gel running at $298 \mathrm{~K}$ in the dark with Tris-acetate-EDTA (TAE) buffer, and the voltage was set at $25 \mathrm{~V}$. There was no separation step before the samples were loaded onto the gel to remove weakly bound complex, if any. The gels were then stained with $\mathrm{EtBr}$, followed by photography with a transilluminator.

As seen in Figure S17, no significant changes in the mobilities of supercoiled (SC) or open circle forms (OC) were observed even at very high concentrations of $\mathrm{Ru}$ compounds $\left(r_{\mathrm{i}}=1\right)$, indicating that these complexes do not unwind DNA and do not form DNA adducts. No changes in intensities of SC and OC forms also indicated that the Ru complexes do not cleave DNA in the dark.

Binding to Short Single- or Double-Stranded Oligonucleotides. Binding of complex 2 to short single- or doublestranded synthetic oligonucleotides was also investigated. A 50mer oligonucleotide (single- or double-stranded) was incubated with complex 2 or complex JS2 $\left(r_{\mathrm{i}}=0.5\right.$, concentration of oligonucleotide related to phosphates) in $0.05 \mathrm{M} \mathrm{NaClO}_{4}$ at 310 $\mathrm{K}$ in the dark. After $24 \mathrm{~h}$ the reaction was stopped, and samples were exhaustively dialyzed against water. The ruthenium contents in these samples were determined by FAAS, and the concentrations of DNA were determined by absorption spectroscopy. No Ru associated with single- or double-stranded oligonucleotides treated with complex JS2 was found, whereas $3-4 \%$ of $\mathrm{Ru}$ was bound to single-stranded oligonucleotide on incubation with complex 2 , but no detectable amount of $\mathrm{Ru}$ was bound to double-stranded oligonucleotide.

Effect of Formate on Antiproliferative Activity. The antiproliferative activity of tethered complexes 1-4 against A2780 human ovarian cancer cells in the presence of sodium formate was determined (Figure 8). Experiments included three sets of controls: the first, negative controls, consisted of

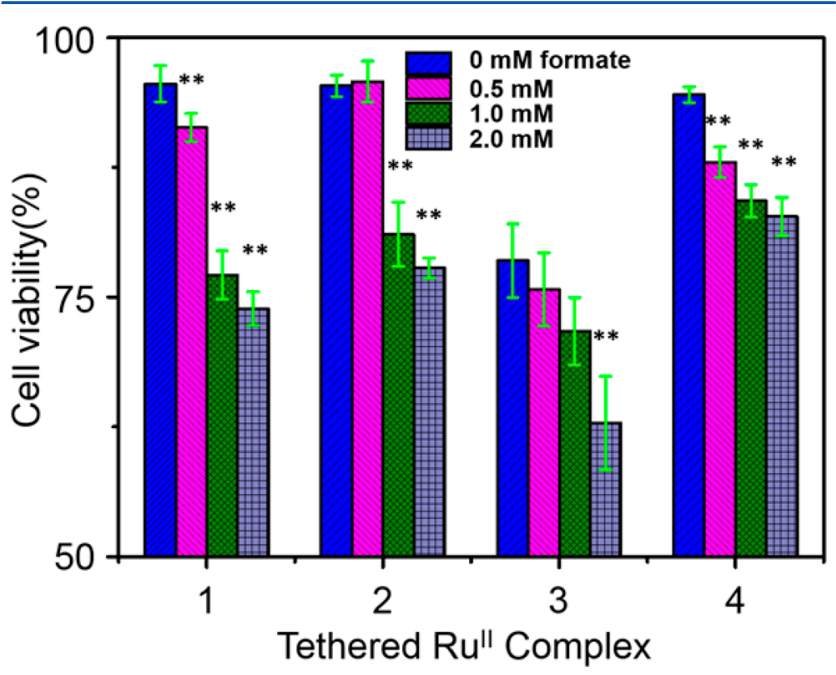

Figure 8. Cell viability of A2780 ovarian cancer cells on exposure for 24 $\mathrm{h}$ to complexes 1-4 (at equipotent $1 / 3 \times \mathrm{IC}_{50}$ concentrations) and sodium formate at concentrations of $0,0.5,1.0$, and $2.0 \mathrm{mM}$. $p$ Values were calculated after a $t$-test against the negative control data: $* p<0.05$, $* * p<0.01$. 
untreated cells (only vehicle exposure), a second set was exposed to three concentrations of sodium formate $(0.5,1$, and $2 \mathrm{mM})$, and a third set was exposed to cisplatin as positive controls. The results indicate that formate alone is not toxic toward A2780 ovarian cancer cells under the conditions used, as the statistical difference between the first two controls was never significant (Table S8 in the Supporting Information). A2780 cancer cells were incubated with equipotent concentrations of complexes 1$4\left(1 / 3 \times \mathrm{IC}_{50}\right)$ and three concentrations of sodium formate $(0.5$, 1 , and $2 \mathrm{mM}$ ) for $24 \mathrm{~h}$. Following $72 \mathrm{~h}$ of recovery time in drugfree medium, cell survival was evaluated using the Sulforhodamine B colorimetric assay. A decrease in cell viability was observed, and importantly this was greater with increasing concentrations of sodium formate. Complex 4 showed the least effect on cell viability, decreasing from $95 \%$ to $81 \%$, while complex 1 exhibited the highest changes, varying from $96 \%$ to $74 \%$ when $2 \mathrm{mM}$ formate was coadministered. Overall, the percentage of cell viability reduction which accompanies formate coadministration follows the order $1>2>3>4$ (percentages of cell survival are given Table S8 in the Supporting Information).

\section{DISCUSSION}

The X-ray crystal structures of complexes 1-4 show that they adopt the well-known "piano-stool" geometry, with nitrogens of the diamine and a chloride bound to the metal center forming the three legs and a phenyl ring forming the seat, being linked to the ethylenediamine by a three-carbon tether. ${ }^{44,45}$ Complexes 1-4 all have similar tethered structures. The length of the bond between $\mathrm{Ru}$ and the deprotonated $\mathrm{N}$ is within the range 2.112$2.121 \AA$, shorter than in the chiral tethered complex $(R, R)$ $\left[\mathrm{Ru}\left(\eta^{6}-\mathrm{Ph}\left(\mathrm{CH}_{2}\right)_{3}-\mathrm{TsDPEN}-\mathrm{N}(\mathrm{H})\right) \mathrm{Cl}\right](2.144(3) \AA)$ and $\left[\left(\eta^{6}-\right.\right.$ $p$-cym) Ru(TsDPEN)Cl] $(2.139(6) \AA)$, while the $\mathrm{Ru}-\mathrm{N}(\mathrm{H})$ bond length is within the range $2.140-2.149 \AA$, which is longer than those in the latter two complexes (2.134(3) and 2.105(6) $\AA$, respectively). ${ }^{38,40,46}$ Complexes $\mathbf{1 - 4}$ have $\mathrm{Ru}-\mathrm{N}\left({ }^{-}\right)$and $\mathrm{Ru}-$ $\mathrm{N}(\mathrm{H})$ bond lengths very similar to those in the complex $\left[\left(\eta^{6}-\right.\right.$ $\mathrm{hmb}) \mathrm{Ru}(\mathrm{TsEn}) \mathrm{Cl}]$ ( $\mathrm{hmb}=$ hexamethylbenzene, 2.129(3) and $2.141(3) \AA$, respectively). ${ }^{36}$ The $\mathrm{N}-\mathrm{Ru}-\mathrm{N}$ angles are in the range $78.54-78.87^{\circ}$, close to those in the chiral tethered $\mathrm{Ru}$ complex $(R, R)-\left[\mathrm{Ru}\left(\eta^{6}-\mathrm{Ph}\left(\mathrm{CH}_{2}\right)_{3}\right.\right.$-TsDPEN-N(H))Cl].38 The remaining bond lengths and angles show no significant difference in comparison to either tethered or nontethered $\mathrm{Ru}$ sulfonyl ethylenediamine complexes.

Complex 2 reacted rapidly with guanine (9-EtG), as studied by NMR at millimolar concentrations. ${ }^{28}$ However, at lower concentrations (micromolar), little binding to DNA was observed when calf thymus and bacterial plasma DNA were exposed to complex 2 , consistent with results reported previously for the nontethered $\mathrm{Ru}^{\mathrm{II}}$ complex $\left[\left(\eta^{6}-p\right.\right.$-cym $\left.) \mathrm{Ru}(\mathrm{TsEn}) \mathrm{Cl}\right]$ (JS2), implying that DNA is not likely to be a target for Ru sulfonamide complexes. ${ }^{37}$ The binding to L-His (as well as L-Cys) suggests that proteins and enzymes may also be targets for these complexes.

Hydride transfer between coenzyme $\mathrm{NAD}^{+}$and $\mathrm{NADH}$ plays a pivotal role in cell metabolism; ${ }^{47}$ this pair of coenzymes is believed to be involved in over 400 cellular reactions. ${ }^{48}$ Studies of $\mathrm{TH}$ reactions for conversion of $\mathrm{NAD}^{+}$to $\mathrm{NADH}$ catalyzed by transition-metal complexes were initiated by Fish and Steckhan. ${ }^{49-51}$ The use of $\mathrm{Ru}^{\mathrm{II}}$ catalysts to mimic the cellular reaction and achieve $\mathrm{TH}$ reduction of $\mathrm{NAD}^{+}$under biologically relevant conditions has been well studied. ${ }^{52,53}$ The en complex RM175 showed strong DNA affinity but low catalytic efficiency toward $\mathrm{TH}$ reduction of $\mathrm{NAD}^{+}\left(\mathrm{TOF}, 0.18 \mathrm{~h}^{-1}\right) ;^{35}$ whereas the introduction of a sulfonyl functional group raised the TOF to $2.88 \mathrm{~h}^{-1}$ (JS2 in Figure 1). ${ }^{35}$ In this work, complexes 1-4 displayed more potent catalytic activity toward $\mathrm{TH}$ of $\mathrm{NAD}^{+}$to $\mathrm{NADH}$. The reaction rate for tosylated complex 2 is ca. $25.8 \times$ and 1.6× faster than those for Ru-en and Ru-TsEn complexes and is comparable to that of the $\mathrm{Rh}^{\mathrm{III}}$ complex $\left[\left(\eta^{5}-\mathrm{Cp} *\right) \mathrm{Rh}\right.$ (bipy)Cl $] \mathrm{PF}_{6}{ }^{54,55}$ This may be facilitated by the longer $\mathrm{Ru}-$ $\mathrm{N}(\mathrm{H})$ and shorter $\mathrm{Ru}-\mathrm{N}\left({ }^{-}\right)$bond lengths allowing the tethered complex to approach $\mathrm{NAD}^{+}$more closely in the $\mathrm{TH}$ catalytic cycle, together with the ease of hydrolysis of the tethered complexes. In general, the TOF values determined by UV-vis are similar to those determined by NMR spectroscopy (Table 2), the small difference probably arising from the mole ratios of formate used, since the TOF increases with an increase in the molar ratio of formate. ${ }^{36}$ It appears that the presence of the electron-withdrawing sulfonamide on the chelating ligand gives rise to higher catalytic activity, consistent with the previous reported TH reduction of aldehydes and quinoxalines. ${ }^{36,56,57}$

As a major peptide in cells, glutathione ( $\gamma$-L-Glu-L-Cys-Gly, GSH) plays a significant role in cell metabolism: e.g., in the maintenance of cellular redox state and signal transduction. ${ }^{58}$ It functions as an important reducing agent (GSH/GSSG couple) and has a high affinity for transition-metal complexes. ${ }^{59}$ Acquired drug resistance in cancer cells is often associated with overexpression of GSH, which can act as a detoxification agent. ${ }^{60}$ Complex $2\left(2 \mathrm{mM}, \mathrm{MeOD}-d_{4} / \mathrm{H}_{2} \mathrm{O}(1 / 4 \mathrm{v} / \mathrm{v})\right)$ reacted rapidly with $\mathrm{GSH}\left(0.5-10 \mathrm{~mol}\right.$ equiv, $\mathrm{pH}^{*} 7.1,310 \mathrm{~K}$; Figure $\mathrm{S} 2$ in the Supporting Information) to form the adduct 2-SG, but this decomposed within $24 \mathrm{~h}$, as shown in Figure 4, at $310 \mathrm{~K}$ in aqueous solution with eventual loss of the chelated tethered sulfonyl-ethylenediamine ligand (Figure 4 and Figure S15). Complex 1 reacted with GSH similarly to complex 2 . Complexes 3 and 4 also reacted rapidly under NMR conditions (millimolar concentrations) but appeared to form more stable 3-SG and 4SG complexes. This high thiol affinity may mean that these tethered $\mathrm{Ru}$ complexes bind rapidly to GSH on entering cells, blocking the approach of $\mathrm{Ru}$ complex to DNA, and the decomposition of the adduct may lead to metabolites that are toxic to cells. ${ }^{59}$ This may partially explain why $\mathrm{TH}$ reduction of $\mathrm{NAD}^{+}$was hampered in the presence of GSH and only a limited increase in potency is observed in A2780 cancer cells exposed to complex $\mathbf{2}$ and sodium formate, in comparison to the Ru complex $\left[\left(\eta^{6}-p\right.\right.$-cym $\left.) \mathrm{Ru}(\mathrm{TsEn}) \mathrm{Cl}\right]$, even though the $\mathrm{TH}$ reduction of $\mathrm{NAD}^{+}$was believed to be taking place in the cancer cells. ${ }^{37}$

Cisplatin is frequently used clinically in combination chemotherapy, especially for ovarian and testicular cancers. ${ }^{61}$ However, poor 5 year survival rates in ovarian cancer patients are partly attributable to the development of drug resistance. ${ }^{62}$ Complex 2 showed much lower cross-resistance with cisplatin (resistance index ca. 2 versus 11 for cisplatin) despite the low cell uptake in resistant human ovarian A2780Cis cancer cells. Furthermore, the higher selectivity index between MRC5 normal cells and A2780Cis cancer cells (2.6 for complex 2 versus 0.95 for cisplatin), indicates that complex 2 might be able to overcome cisplatin resistance with fewer side effects.

Cellular accumulation is an important factor in drug cytotoxicity. ${ }^{63}$ Cellular accumulation of $\mathrm{Ru}$ from complexes 2 and 4 in A2780 and A2780Cis cancer cells did not correlate with their cytotoxicity $\left(\mathrm{IC}_{50}\right)$. The cellular accumulation of $\mathrm{Ru}$ from complex 2 is similar in A2780 vs A2780 Cis cells, yet its $\mathrm{IC}_{50}$ varies between 7.3 and $15 \mu \mathrm{M}$. In comparison, complex 4 loses its activity in the resistant cell line, yet its cellular accumulation is notably increased. TOFs for $\mathrm{NAD}^{+} \mathrm{TH}$ by formate for complexes 
1-4 do not correlate with the reduction of cell viability induced by $2 \mathrm{mM}$ sodium formate, following the order $\mathbf{4}<\mathbf{3}<\mathbf{2}<\mathbf{1}$. This may imply that factors other than the catalytic conversion of $\mathrm{NAD}^{+}$to $\mathrm{NADH}$ are also involved in the processes which determine the cellular mechanism of antiproliferative activity.

In contrast to the negative control (A2780 cells not treated, Figure 6), complex 2 can induce concentration-dependent $G_{1}$ cell cycle arrest, which inhibits cell division. Previously, $\mathrm{Ru}^{\mathrm{II}}$ complexes have been reported to induce $\mathrm{G} 1$ arrest, e.g., the $\mathrm{Ru}$ Norharman complex $\left[\mathrm{Ru}(\text { bipy })_{2}(9 \mathrm{H} \text {-pyrido- }[3,4-b] \text { indole })_{2}\right]^{2+}$ and $\left[\mathrm{Ru}\left(\eta^{6}-p\right.\right.$-cym $)\left(p\right.$-Impy-NMe $\left.\left.{ }_{2}\right) \mathrm{Cl}\right] .{ }^{64,65}$ Clinical anticancer drugs, for instance clotrimazole and paclitaxel, can also induce $\mathrm{G}_{1}$ cell cycle arrest. ${ }^{66,67}$ Paclitaxel can inhibit cell proliferation by activation of p53 tumor suppressor gene. ${ }^{67}$ Microtubules are also potential targets. They are important cycloskeletal polymers, which can form a constantly reorganized solid backbone that serves as a polarity information source, to separate chromosomes through cell division. ${ }^{68}$ The recently reported $\mathrm{Ru}^{\mathrm{II}}$ complexes $\left[\mathrm{Ru}\left(\eta^{6}-\mathrm{Ph}\left(\mathrm{CH}_{2}\right)_{3}-\mathrm{TsDPEN}-\mathrm{N}(\mathrm{H})\right) \mathrm{Cl}\right](R, R$ or $S, S)$ distribute mainly in the cycloskeleton and can effectively target and inhibit microtubule polymerization. ${ }^{42}$ In view of its structural similarity, complex 2 might also potentially target microtubules and subsequently trigger G1 cell arrest.

ROS are important factors in cell signaling and can control cell survival, cell proliferation, and the maintenance of cell redox homeostasis. ${ }^{69}$ A moderate level of intracellular ROS would encourage the growth of cancer cells; however, higher levels will cause damage and even induce apoptosis of cancer cells. ${ }^{70}$ Complex 2 significantly increased the ROS level in A2780 cancer cells at $\mathrm{IC}_{50}$ concentrations, giving over $80 \%$ of cancer cells total oxidative stress, which may contribute to cell death.

\section{CONCLUSIONS}

The four tethered $\mathrm{Ru}^{\mathrm{II}}$ catalysts $\mathbf{1}-\mathbf{4}$ have been synthesized and their structures determined by X-ray crystallography. All of the complexes exhibit potent reductive catalytic transfer hydrogenation activity using formate as the hydride source in aqueous media, as shown by the conversion of coenzyme $\mathrm{NAD}^{+}$to $\mathrm{NADH}$, and follow the general reactivity trend $\mathbf{1}<\mathbf{2}<\mathbf{3}<\mathbf{4}$. Coincubation of complexes 1-4 with A2780 cancer cells in the presence of formate resulted in the dose-dependent reduction of cell viability (Figure 8 ). Formate alone under similar conditions had no effect on cell viability. Such a combination of catalyst and nontoxic cocatalyst may provide a promising strategy for the design of new drugs which can be used at low concentrations and have new mechanisms of action that are effective against resistant cancers.

These complexes exhibit moderate to good anticancer activity toward A2780, A2780 Cis, A549, MCF7, and HEPG2 cancer cell lines. Some of the complexes displayed cytotoxicity comparable to that of the clinically used drug cisplatin. Complex 2 ( $\left[\mathrm{Ru}\left(\eta^{6}\right.\right.$ $\mathrm{Ph}\left(\mathrm{CH}_{2}\right)_{3}$-ethylenediamine- $\mathrm{N}$-Ts $\left.\left.) \mathrm{Cl}\right]\right)$ in particular exhibits a low cross-resistance with cisplatin toward A2780 human ovarian cancer cells and unlike cisplatin does not appear to involve a DNA-targeting mechanism of action.

Complex 2 reacts rapidly with GSH to form a 2-SG adduct, which can effectively block the $\mathrm{TH}$ reduction of $\mathrm{NAD}^{+}$. At millimolar NMR concentrations, the chelated tethered ligand was readily displaced by excess GSH, but such reactions may be much slower in cells where the $\mathrm{Ru}$ concentration would be ca. $200 \times$ lower. It is possible that these $\mathrm{TH}$ reactions are faster in cells if they take place in compartments where the dielectric constant is lower than that of water, since higher percentages of
DMSO increased the rate (Figure S11 in the Supporting Information), as was found earlier for $\mathrm{MeOH}$ in related systems. ${ }^{36}$ It is also possible that these tethered $\mathrm{Ru}^{\mathrm{II}}$ complexes can target proteins and enzymes in cells, binding e.g., to histidine as well as the cysteine residues (Figures S10 and S12). However, the contribution of such interactions to the biological activity remains to be investigated.

Concentration-dependent $G_{1}$ cell cycle arrest was observed on exposure of A2780 cells to complex 2 . In addition, complex $\mathbf{2}$ can induce a high level of intracellular ROS, which may provide a basis for killing cancer cells.

\section{EXPERIMENTAL SECTION}

Materials. Ruthenium trichloride was purchased from Precious Metals Online (PMO Pty Ltd.). $\beta$-Nicotinamide adenine dinucleotide hydrate $\left(\mathrm{NAD}^{+}\right)$was purchased from Sigma-Aldrich. Methylsulfonyl chloride, toluenesulfonyl chloride, 4-trifluoromethylbenzenesulfonyl chloride, and 4-nitrobenzenesulfonyl chloride were obtained from Fluka and Sigma-Aldrich. Glutathione was obtained from Alfa Aesar. The A2780 ovarian, A2780 Cis ovarian, A549 lung, HEPG2 hepatocellular, and MCF7 breast human adenocarcinoma cell lines as well as MRC5 human fibroblast cells were purchased from the European Collection of Animal Cell Culture (ECACC, Salisbury, U.K.). Propidium iodide (>94\%) and RNase A were obtained from SigmaAldrich.

Syntheses. To a stirred solution of 3-(1,4-cyclohexadien-1-yl)-1propanol $(1.21 \mathrm{~g}, 9.18 \mathrm{mmol})$ in DCM $(25 \mathrm{~mL})$ was added $\mathrm{NEt}_{3}(2.7$ $\mathrm{mL}, 19.28 \mathrm{mmol}$ ), and the resulting solution was cooled to $273 \mathrm{~K}$. A solution of methanesulfonyl chloride $(1.1 \mathrm{~mL}, 13.8 \mathrm{mmol})$ was added over a period of $20 \mathrm{~min}$, and the internal temperature was kept at $278 \mathrm{~K}$. After $30 \mathrm{~min}$, the solution was warmed to ambient temperature and stirred overnight. The reaction solution was quenched with saturated $\mathrm{NaHCO}_{3}$ solution, washed with water and brine, and dried over $\mathrm{Mg}_{2} \mathrm{SO}_{4}$. The mesylate product was carried forward directly to the next step. A solution of the mesylate derivative in $10 \mathrm{~mL}$ of 1,2 dimethoxyethane (DME) was added slowly over a period of $5 \mathrm{~min}$ to a stirred solution of monosulfonated ethylenediamine $(9.25 \mathrm{mmol})$ in 1,2-dimethoxyethane $(20 \mathrm{~mL})$ and $\mathrm{NEt}_{3}(2.7 \mathrm{~mL}, 19.43 \mathrm{mmol})$ at $333 \mathrm{~K}$. The resulting solution was heated to $353 \mathrm{~K}$ and stirred overnight. The reaction was quenched with saturated $\mathrm{NaHCO}_{3}$ solution. The reaction mixture was worked up with water and brine and dried over $\mathrm{Mg}_{2} \mathrm{SO}_{4}$. The desired ligands were isolated as yellow oils by silica column chromatography with EtOAc and hexane as eluents.

To a stirred solution of tethered ethylenediamine ligands $(0.808$ $\mathrm{mmol})$ in anhydrous $\mathrm{EtOH}(15 \mathrm{~mL})$ was added concentrated $\mathrm{HCl}(0.12$ $\mathrm{mL}, 35 \%, 1.21 \mathrm{mmol}$ ) at $273 \mathrm{~K}$. The solution was heated at $333 \mathrm{~K}$ for 30 $\mathrm{min}$. After this time the solution was heated to $348 \mathrm{~K}$ and a solution of $\mathrm{RuCl}_{3}(0.110 \mathrm{~g}, 0.533 \mathrm{mmol})$ in EtOH $(15 \mathrm{~mL})$ and water $(0.5 \mathrm{~mL})$ was added dropwise over $20 \mathrm{~min}$. The solution was stirred at $348 \mathrm{~K}$ overnight and cooled, hexane $(60 \mathrm{~mL})$ added with vigorous stirring, and the resulting solid collected by filtration. The solid (dimer precursor) was then washed with hexane and dried under high vacuum to give a dark brown solid. The filtrate was concentrated to give an orange powder.

To a stirred solution of dimer precursors $(0.22 \mathrm{mmol})$ in DCM (50 $\mathrm{mL})$ at $273 \mathrm{~K}$ was added $\mathrm{N}, \mathrm{N}$-diisopropylethylamine $(3.0 \mathrm{~mL}, 1.70$ $\mathrm{mmol}$ ), and the solution was stirred at ambient temperature for $2 \mathrm{~h}$. The solution was then filtered over Celite, and the DCM was removed by rotary evaporation. EtOH was added to the resulting paste and stored in the freezer for $3 \mathrm{~h}$ before the cold solution was filtered, and the orange precipitate was collected. The precipitate was washed with further portions of cold $\mathrm{EtOH}$. The desired ruthenium complex was isolated by silica column chromatography with $\mathrm{MeOH}$ and DCM $(1 / 10 \mathrm{v} / \mathrm{v})$.

$\left[\mathrm{Ru}\left(\eta^{6}-\mathrm{Ph}\left(\mathrm{CH}_{2}\right)_{3}\right.\right.$-ethylenediamine- $\left.\left.\mathrm{N}-\mathrm{Ms}\right) \mathrm{Cl}\right]$ (1). The general synthesis of tethered $\mathrm{Ru}$ complexes followed a reported protocol. ${ }^{43}$ Yield: $47 \mathrm{mg}(60 \%) .{ }^{1} \mathrm{H}$ NMR $\left(400 \mathrm{MHz}, \mathrm{MeOD}-d_{4}\right): \delta_{\mathrm{H}} 1.98-2.04(\mathrm{~m}, 1 \mathrm{H})$, $2.29-2.41(\mathrm{~m}, 4 \mathrm{H}), 2.48-2.51(\mathrm{~m}, 1 \mathrm{H}), 2.76(\mathrm{~s}, 3 \mathrm{H}), 2.79-2.82(\mathrm{~m}$, $2 \mathrm{H}), 2.87(\mathrm{~d}, 1 \mathrm{H}, J=7.7 \mathrm{~Hz}), 3.24-3.28(\mathrm{~m}, 1 \mathrm{H}), 5.14-5.20(\mathrm{~m}, 2 \mathrm{H})$, 5.71-5.72 (m, 1H), 5.83-5.88 (m, 2H). ${ }^{13} \mathrm{C}$ NMR (125.7 MHz, 
DMSO- $\left.d_{6}\right): \delta_{\mathrm{C}} 33.3,43.8,52.7,56.8,62.0,78.5,82.1,82.9,95.3,98.0$, 105.5. HR-MS: calcd for $\left[\mathrm{C}_{13} \mathrm{H}_{22} \mathrm{ClN}_{2} \mathrm{O}_{2} \mathrm{SRu}\right]^{+} \mathrm{m} / z$ 357.0211, found $m / z$ 357.0211. Anal. Calcd for $\left[\mathrm{C}_{12} \mathrm{H}_{19} \mathrm{ClN}_{2} \mathrm{O}_{2} \mathrm{RuS}\left(\mathrm{H}_{2} \mathrm{O}\right)_{0.6}\right]$ : C, 35.79; $\mathrm{H}, 5.06$; N, 6.96. Found: C, 35.83; H, 4.91; N, 6.94.

$\left[\mathrm{Ru}\left(\eta^{6}-\mathrm{Ph}\left(\mathrm{CH}_{2}\right)_{3}\right.\right.$-ethylenediamine-N-Ts)Cl] (2). The synthesis of complex 2 (but not its X-ray structure) was reported previously by one of us. ${ }^{43}$ The method described above for complex 1 was used. Recrystallization from methanol resulted in a bright red solid. Yield: 63 $\operatorname{mg}(63 \%) .{ }^{1} \mathrm{H} \mathrm{NMR}\left(400 \mathrm{MHz}, \mathrm{CDCl}_{3}\right): \delta_{\mathrm{H}} 7.73(\mathrm{~d}, 2 \mathrm{H}, J=8.2 \mathrm{~Hz})$, $7.15(\mathrm{~d}, 2 \mathrm{H}, J=8.2 \mathrm{~Hz}), 6.36(\mathrm{t}, 1 \mathrm{H}, J=5.6 \mathrm{~Hz}), 5.96(\mathrm{t}, 1 \mathrm{H}, J=5.6 \mathrm{~Hz})$, $5.83(\mathrm{t}, 1 \mathrm{H}, J=5.8 \mathrm{~Hz}), 5.01(\mathrm{~d}, 1 \mathrm{H}, J=5.6 \mathrm{~Hz}), 4.91(\mathrm{~d}, 1 \mathrm{H}, J=5.8 \mathrm{~Hz})$, $3.79(\mathrm{~s}, 1 \mathrm{H}), 3.30-3.23(\mathrm{~m}, 1 \mathrm{H}), 3.03(\mathrm{dd}, 1 \mathrm{H}, J=11.5 \mathrm{~Hz}, 4.2 \mathrm{~Hz})$, 2.79-2.71 (m, 1H), 2.66-2.62 (m, 1H), 2.43-2.36 (m, 3H), $2.34(\mathrm{~s}$, $3 \mathrm{H}), 2.27-2.19(\mathrm{~m}, 2 \mathrm{H}), 2.08-1.99(\mathrm{~m}, 1 \mathrm{H}) .{ }^{13} \mathrm{C}$ NMR $(125.7 \mathrm{MHz}$, DMSO-d $\left.{ }_{6}\right): \delta_{\mathrm{C}} 26.1,33.2,33.5,52.2,56.7,62.0,78.9,82.1,83.2,94.5$, 97.6, 104.9, 132.1, 133.6, 144.5, 146.9. HR-MS: calcd for $\left[\mathrm{C}_{18} \mathrm{H}_{23} \mathrm{~N}_{2} \mathrm{O}_{2} \mathrm{RuS}\right]^{+} m / z$ 433.0524, found $m / z$ 433.0522. Anal. Calcd for $\left[\mathrm{C}_{18} \mathrm{H}_{23} \mathrm{ClN}_{2} \mathrm{O}_{2} \mathrm{RuS}\left(\mathrm{H}_{2} \mathrm{O}\right)_{0.1}\right]: \mathrm{C}, 46.02 ; \mathrm{H}, 4.98 ; \mathrm{N}, 5.96$. Found: $\mathrm{C}$, 46.03; H, 4.92; N, 5.93 .

$\left[\mathrm{Ru}\left(\eta^{6}-\mathrm{Ph}\left(\mathrm{CH}_{2}\right)_{3}\right.\right.$-ethylenediamine- $\left.\left.\mathrm{N}-\mathrm{Tf}\right) \mathrm{Cl}\right]$ (3). Complex 3 was obtained following the method described above for complex 1 . Recrystallization from methanol resulted in a brownish-red solid. Yield: $38 \mathrm{mg}(36 \%) .{ }^{1} \mathrm{H}$ NMR (400 MHz, DMSO- $\left.d_{6}\right): \delta_{\mathrm{H}} 1.84-1.86(\mathrm{~m}$, $1 \mathrm{H}), 2.10(\mathrm{t}, 1 \mathrm{H}, J=11.2 \mathrm{~Hz}), 2.25(\mathrm{t}, 2 \mathrm{H}, J=9.7 \mathrm{~Hz}), 2.33-2.46(\mathrm{~m}$, $2 \mathrm{H}), 2.64(\mathrm{~d}, 1 \mathrm{H}, J=8.9 \mathrm{~Hz}), 2.75(\mathrm{q}, 1 \mathrm{H}, J=9.7 \mathrm{~Hz}, 21.9 \mathrm{~Hz}),, 2.85(\mathrm{~d}$, $1 \mathrm{H}, J=8.0 \mathrm{~Hz}), 3.14(\mathrm{~s}, 1 \mathrm{H})$ (broad single peak), $4.35(\mathrm{~s}, 1 \mathrm{H})$ (broad single peak), $5.27(\mathrm{~d}, 1 \mathrm{H}, J=4.9 \mathrm{~Hz}), 5.40(\mathrm{~d}, 1 \mathrm{H}, J=5.6 \mathrm{~Hz}), 5.83-5.89$ $(\mathrm{m}, 2 \mathrm{H}), 5.97(\mathrm{t}, 1 \mathrm{H}, J=5.1 \mathrm{~Hz}), 7.75(\mathrm{~d}, 2 \mathrm{H}, J=8.0 \mathrm{~Hz}), 7.93(\mathrm{~d}, 2 \mathrm{H}, J$ $=8.0 \mathrm{~Hz}) \cdot{ }^{13} \mathrm{C}$ NMR $\left(125.7 \mathrm{MHz}\right.$, DMSO- $\left.d_{6}\right): \delta_{\mathrm{C}} 33.2,33.4,52.3,56.7$, 61.9, 79.2, 81.9, 83.6, 94.8, 97.8, 105.3, 130.1, 132.9, 134.8, 135.1, 135.0. ${ }^{19} \mathrm{~F}$ NMR (376.4 MHz, DMSO- $\left.d_{6}\right): \delta_{\mathrm{F}}-61.02$. HR-MS: calcd for $\left[\mathrm{C}_{18} \mathrm{H}_{20} \mathrm{~N}_{2} \mathrm{~F}_{3} \mathrm{O}_{2} \mathrm{SRu}\right]^{+} m / z 487.0241$, found $m / z$ 487.0240. Anal. Calcd for $\left[\mathrm{C}_{18} \mathrm{H}_{20} \mathrm{ClF}_{3} \mathrm{~N}_{2} \mathrm{O}_{2} \mathrm{RuS}\left(\mathrm{H}_{2} \mathrm{O}\right)_{0.1}\right]: \mathrm{C}, 41.28 ; \mathrm{H}, 3.89 ; \mathrm{N}, 5.35$. Found: C, 41.20; H, 3.65; N, 5.26.

$\left[\mathrm{Ru}\left(\eta^{6}-\mathrm{Ph}\left(\mathrm{CH}_{2}\right)_{3}\right.\right.$-ethylenediamine- $\left.\left.\mathrm{N}-\mathrm{Nb}\right) \mathrm{Cl}\right]$ (4). Complex 4 was obtained following the method described above for complex 1 . Recrystallization from methanol and diethyl ether resulted in a bright red solid. Yield: $44 \mathrm{mg}(43 \%) .{ }^{1} \mathrm{H}$ NMR $\left(300 \mathrm{MHz}, \mathrm{CDCl}_{3}\right): \delta_{\mathrm{H}} 2.00-$ $2.08(\mathrm{~m}, 1 \mathrm{H}), 2.14-2.58(\mathrm{~m}, 2 \mathrm{H}), 2.34-2.50(\mathrm{~m}, 3 \mathrm{H}), 2.69-2.82(\mathrm{~m}$, $2 \mathrm{H}), 3.12(\mathrm{dd}, 1 \mathrm{H}, J=5.5 \mathrm{~Hz}, 14.8 \mathrm{~Hz}), 3.23-3.32(\mathrm{~m}, 1 \mathrm{H}), 3.70(\mathrm{~s}$, $1 \mathrm{H})$ broad single peak, $4.92(\mathrm{~d}, 1 \mathrm{H}, J=7.9 \mathrm{~Hz}), 5.00(\mathrm{~d}, 1 \mathrm{H}, J=7.6 \mathrm{~Hz})$, $5.86(\mathrm{t}, 1 \mathrm{H}, J=7.6 \mathrm{~Hz}),, 5.96(\mathrm{t}, 1 \mathrm{H}, J=8.1 \mathrm{~Hz}), 6.30(\mathrm{t}, 1 \mathrm{H}, J=7.3 \mathrm{~Hz})$, $7.96(\mathrm{~d}, 2 \mathrm{H}, J=11.6 \mathrm{~Hz}), 8.18(\mathrm{~d}, 2 \mathrm{H}, J=11.8 \mathrm{~Hz}) .{ }^{13} \mathrm{C}$ NMR $(125.7$ MHz, DMSO-d $\left.{ }_{6}\right): \delta_{\mathrm{C}} 33.1,33.5,52.4,56.7,61.8,79.3,81.9,83.8,94.8$, $97.8,105.5,128.4,133.4,153.1,155.0$. HR-MS: calcd for $\left[\mathrm{C}_{17} \mathrm{H}_{20} \mathrm{~N}_{3} \mathrm{O}_{4} \mathrm{SRu}\right]^{+} \mathrm{m} / z$ 464.0218, found $\mathrm{m} / z$ 464.0216. Anal. Calcd for $\left[\mathrm{C}_{17} \mathrm{H}_{20} \mathrm{ClN}_{3} \mathrm{O}_{2} \mathrm{RuS}\left(\mathrm{H}_{2} \mathrm{O}\right)_{0.5}\right]$ : C, 40.20; H, 4.17; N, 8.27. Found: $\mathrm{C}$, 40.26; H, 3.89; N, 8.04.

Instruments and Methods. NMR Spectroscopy. ${ }^{1} \mathrm{H}$ NMR spectra were obtained on either a Bruker HD-400, or a AVIII 600 spectrometer at 298 or $310 \mathrm{~K}$. Data were processed by Topspin-NMR version $3.5 \mathrm{pl} 7$ (Bruker U.K. Ltd.), with NMR proton chemical shifts internally referenced to TMS via 1,4-dioxane in $\mathrm{D}_{2} \mathrm{O}(\delta 3.75)$ or residual MeOD$d_{4}(\delta 3.31 \mathrm{ppm})$, DMSO- $d_{6}(\delta 2.50 \mathrm{ppm})$ or $\mathrm{CDCl}_{3}(\delta 7.26 \mathrm{ppm}) .1 \mathrm{D}$ spectra were recorded using standard pulse sequences. NMR spectra were acquired with 16 transients into $32 \mathrm{k}$ data points over a spectral width of $14 \mathrm{ppm}$ and 32 transients into $32 \mathrm{k}$ data points over a spectral width of $30 \mathrm{ppm}$ with $2 \mathrm{~s}$ relaxation delay for the kinetic experiments.

High-Resolution Mass Spectrometry (HRMS). All samples were prepared in methanol. High-resolution mass spectrometry data were obtained on a Bruker Maxis Plus Q-TOF instrument.

Elemental Analysis. Elemental analyses were performed by Warwick Analytical Service using an Exeter Analytical elemental analyzer (CE440).

$X$-ray Crystallography. Single crystals of $\mathbf{1 - 4}$ were obtained from a slow diffusion of diethyl ether into methanol solutions of the complexes. Suitable crystals were selected and mounted on a glass fiber with Fromblin oil and placed on an Xcalibur Gemini diffractometer with a Ruby CCD area detector. The crystals were kept at $150 \pm 2 \mathrm{~K}$ during data collection. Using Olex2, ${ }^{71}$ the structure was solved with the
ShelXT ${ }^{72}$ structure solution program using direct methods and refined with the ShelXL ${ }^{73}$ refinement package using least-squares minimization. The data were processed by the modeling program Mercury 3.8. X-ray crystallographic data for complexes 1-4 have been deposited in the Cambridge Crystallographic Data Center (CCDC) under the deposition numbers CCDC 1823316-1823319 (complexes 4, 3, 2, and $\mathbf{1}$, respectively).

ICP-MS/-OES Determination. ICP-MS and ICP-OES analyses were carried out on Agilent Technologies 7500 series and PerkinElmer Optima 5300 DV series instruments, respectively. The double-deionized (DDW) water used for both analyses was from a Millipore Milli-Q water purification system and a USF Elga UHQ water deionizer. The Ruthenium Specpure plasma standard (ruthenium chloride, $1004 \pm 5$ $\mu \mathrm{g} / \mathrm{mL}$ in $10 \% \mathrm{v} / \mathrm{v}$ hydrochloric acid) was diluted with $3.6 \% \mathrm{v} / \mathrm{v} \mathrm{HNO}_{3}$, and calibrants were prepared freshly at concentrations of $0.1-500 \mathrm{ppb}$ for ICP-MS and 50-700 ppb for ICP-OES. In particular, calibration standards for ICP-OES analysis were adjusted with standard sodium chloride (TraceSELECT) solution to match the sample salinity. The instrument was set to detect ${ }^{101} \mathrm{Ru}$ with typical detection using no-gas mode for ICP-MS analysis.

TOFs Determined by UV-Vis Spectroscopy. Complexes 1-4 were dissolved in $\mathrm{DMSO} / \mathrm{H}_{2} \mathrm{O}(1 / 9 \mathrm{v} / \mathrm{v})(84 \mu \mathrm{M})$ in a glass vial. Solutions of sodium formate $(102 \mathrm{mM})$ and $\mathrm{NAD}^{+}$in $\mathrm{H}_{2} \mathrm{O}(510 \mu \mathrm{M})$ were also prepared and then mixed at $310 \mathrm{~K}$. In a typical experiment, an aliquot of $330 \mu \mathrm{L}$ from each solution was placed in a $1 \mathrm{~mL}$ cuvette and the $\mathrm{pH}$ adjusted to 7.2 before the sample was introduced into the UV-vis instrument, giving a total volume of $1 \mathrm{~mL}$ (final concentrations were $\mathrm{Ru}$ complex $28 \mu \mathrm{M}, \mathrm{NAD}^{+} 170 \mu \mathrm{M}, \mathrm{NaHCO}_{2} 34 \mathrm{mM}$, molar ratio $1 / 6$ / 1200). UV spectra were recorded every 5 min until completion of the reaction. The spectrum was monitored for an increase in the band at 340 $\mathrm{nm}$, which corresponds to the absorption of NADH.

TOFs Determined by NMR. Complexes 1-4 were dissolved in DMSO- $d_{6} / \mathrm{D}_{2} \mathrm{O}(3 / 2 \mathrm{v} / \mathrm{v} ; 1.4 \mathrm{mM})$ in a glass vial. Aliquots $(200 \mu \mathrm{L})$ of solutions of sodium formate $(35 \mathrm{mM})$ and $\operatorname{NAD}^{+}(5.6 \mathrm{mM})$ in $\mathrm{D}_{2} \mathrm{O}$ were added, and the $\mathrm{pH}^{*}$ was adjusted to $7.2 \pm 0.1$, for a final volume of $0.64 \mathrm{~mL}$ (Ru complex $0.44 \mathrm{mM}, \mathrm{NAD}^{+} 1.75 \mathrm{mM}, \mathrm{NaHCO}_{2} 10.94 \mathrm{mM}$; molar ratio $1 / 4 / 25)$. The solution was transferred to a $5 \mathrm{~mm}$ NMR tube, and a ${ }^{1} \mathrm{H}$ NMR spectrum was recorded at $310 \mathrm{~K}$ every $162 \mathrm{~s}$ until the completion of the reaction. Molar ratios of $\mathrm{NAD}^{+}$and $\mathrm{NADH}$ were determined by integrating the peaks corresponding to resonances for $\mathrm{NAD}^{+}(9.33 \mathrm{ppm})$ and 1,4-NADH $(6.96 \mathrm{ppm})$. The turnover number (TON) for the reaction was calculated

$$
\mathrm{TON}=\frac{I_{6.96}}{I_{6.96}+I_{9.93}} \frac{\left[\mathrm{NAD}^{+}\right]}{[\text {catalyst }]}
$$

where $I_{n}$ is the integral of the signal at $n$ ppm and $\left[\mathrm{NAD}^{+}\right]$is the concentration of $\mathrm{NAD}^{+}$at the start of the reaction.

Reaction with GSH. Reactions of complex $2\left(2 \mathrm{mM}, \mathrm{MeOD}-d_{4} / \mathrm{D}_{2} \mathrm{O}\right.$ $(2 / 8 \mathrm{v} / \mathrm{v}))$ and $\mathrm{GSH}\left(\right.$ in $\left.\mathrm{D}_{2} \mathrm{O}\right)$ in the mole ratio of $1 / X$, where $X=0.2$, $0.5,1,2,5$, and 10 , were studied by ${ }^{1} \mathrm{H}$ NMR $(600 \mathrm{MHz})$ spectroscopy under conditions of MeOD $-d_{4} / \mathrm{D}_{2} \mathrm{O}(1 / 9 \mathrm{v} / \mathrm{v}), \mathrm{pH}^{*} 7.2$, and $310 \mathrm{~K}$. Each reaction was complete within $10 \mathrm{~min}$. A second set of experiments investigated the time dependence of reactions of 2 with GSH $(20 \mathrm{mM})$ in the mole ratio of $1 / 20$, monitored by ${ }^{1} \mathrm{H}$ NMR $(600 \mathrm{MHz})$ spectroscopy under conditions similar to those above $\left(\mathrm{pH}^{*} 7.2,310 \mathrm{~K}\right)$, from $5 \mathrm{~min}$ to $24 \mathrm{~h}$.

Cell Culture. A2780 and A2780Cis human ovarian, A549 human lung, HEPG 2 human hepatocellular, MCF 7 human breast cancer, and MRC 5 human normal fibroblast cell lines were grown in Roswell Park Memorial Institute medium (RPMI-1640) supplemented with 10\% of fetal calf serum, $1 \%$ of $2 \mathrm{mM}$ glutamine, and $1 \%$ penicillin/streptomycin. All cells were grown as adherent monolayers at $310 \mathrm{~K}$ with $5 \% \mathrm{CO}_{2}$ humidified, and all cells were passaged at ca. $80 \%$ confluency.

$I C_{50}$ and in Vitro Cytotoxicity Determination. The antiproliferative activity and cytotoxicity of complexes 1-4 were determined in five different cancer cell lines and one human normal cell line. In general, about 5000 cells per well were seeded in 96 -well plates. The plates were preincubated with drug-free medium at $310 \mathrm{~K}$ for $48 \mathrm{~h}$ before adding the tested compounds (various concentrations). Stock solutions of 
complexes 1-4 were prepared in DMSO/cell culture medium, and exact complex concentrations were determined by ICP-OES. After $24 \mathrm{~h}$ drug exposure, supernatants were removed by suction and each well was washed with PBS. A further cell recovery for $72 \mathrm{~h}$ was allowed in drugfree medium at $310 \mathrm{~K}$. The sulforhodamine B (SRB) assay was used to determine cell viability. $\mathrm{IC}_{50}$ values, as the concentration that causes $50 \%$ cell death, were determined as duplicates of triplicates in two independent sets of experiments, and their standard deviations were calculated.

Cellular Ru Accumulation. Cellular Ru accumulations for complexes 2 and 4 were determined on A2780 ovarian and A2780 cisplatinresistant ovarian cancer cells. Approximately $2 \times 10^{6}$ cells were seeded in a six-well plate and preincubated in drug-free medium at $310 \mathrm{~K}$ for $24 \mathrm{~h}$, and stock solutions of both complexes were prepared in a mixture of $\mathrm{DMSO} /$ cell culture medium and their accurate $\mathrm{Ru}$ concentrations were determined by ICP-OES. Working solutions were then obtained by dilution in cell culture medium. Both cancer cell lines were exposed to complexes 2 and 4 for $24 \mathrm{~h}$, at equipotent $\mathrm{IC}_{50}$ concentrations. The experiment did not involve recovery time in drug-free medium. After this time, cells were treated with trypsin and counted and cell pellets were collected. Cell pellets were digested overnight in $200 \mu \mathrm{L}$ concentrated nitric acid $(73 \%)$ at $353 \mathrm{~K}$; the resulting solutions were diluted with double-distilled water to a final concentration of $3.6 \%$ $\mathrm{HNO}_{3}$ (v/v), and the amount of Ru taken up by the cells was determined by ICP-MS (Agilent technologies 7500 series). Data acquisition was carried out in ICP-MS top B.03.05 and processed on offline Data analysis B.03.05. These experiments did not include any cell recovery time in drug-free media; they were carried out in triplicate, and the standard deviations were calculated. Statistical significances of variations were determined using Welch's $t$-tests.

Cell Cycle Analysis. A2780 cells at $1.5 \times 10^{6}$ cells per well were seeded in a six-well plate. Cells were preincubated in drug-free media at $310 \mathrm{~K}$ for $24 \mathrm{~h}$, after which drugs were added at equipotent concentration equal to the $\mathrm{IC}_{50}$ value. After $24 \mathrm{~h}$ of drug exposure, supernatants were removed by suction and cells were washed with PBS. Finally, cells were harvested using trypsin-EDTA and fixed for $2 \mathrm{~h}$ using cold $70 \%$ ethanol. DNA staining was achieved by resuspending the cell pellets in PBS containing propidium iodide (PI) and RNase. Cell pellets were washed and resuspended in PBS before being analyzed in a Becton Dickinson FACScan flow cytometer using excitation of DNA-bound PI at $536 \mathrm{~nm}$, with emission at $617 \mathrm{~nm}$. Data were processed with Flowjo software using a Watson (Pragmatic) fitting model. Welch's $t$-tests were carried out to determine the statistical variations.

ROS Determination. Flow cytometry analysis of ROS/superoxide generation in A2780 cells caused by exposure to complex 2 was carried out using the Total ROS/Superoxide detection kit (Enzo-Life Sciences) according to the instructions. A total of $1.5 \times 10^{6} \mathrm{~A} 2780$ cells per well were seeded in a six-well plate. Cells were preincubated in drug-free media at $310 \mathrm{~K}$ for $24 \mathrm{~h}$ in a $5 \% \mathrm{CO}_{2}$ humidified atmosphere, and then drugs were added to triplicates at $\mathrm{IC}_{50}$ concentration. After $24 \mathrm{~h}$ of drug exposure, supernatants were removed by suction and cells were washed and harvested. Staining was achieved by resuspending the cell pellets in buffer containing the orange/green fluorescent reagents. Cells were analyzed in a Becton Dickinson FACScan flow cytometer using FL1 channel $\mathrm{Ex} / \mathrm{Em} 490 / 525 \mathrm{~nm}$ for the oxidative stress and FL2 channel $\mathrm{Ex} / \mathrm{Em} 550 / 620 \mathrm{~nm}$ for superoxide detection. Positive controls were obtained by exposure of cells to pyocyanin for $30 \mathrm{~min}$. Data were processed using Flowjo software. At all times, samples were kept under dark conditions to avoid light-induced ROS production. Welch's $t$-tests were carried out to establish statistical significance of the variations.

Cell Membrane Integrity Determination. Flow cytometry analysis of the cellular membrane integrity of A2780 cells caused by exposure to complex 2 was carried out using flow cytometry and propidium iodide staining. Briefly, A2780 cells were seeded in six-well plates $\left(1.5 \times 10^{6}\right.$ cells per well) and preincubated for $24 \mathrm{~h}$ in drug-free media at $310 \mathrm{~K}$, after which they were exposed to complex 2 at $\mathrm{IC}_{50}$ concentration. Cells were harvested using trypsin and stained in the dark using a mixture of propidium iodide and RNase without previous fixation of the cells. After staining, cell pellets were analyzed in a Becton Dickinson FACScan Flow
Cytometer and the histograms were analyzed using Flowjo software and their standard deviations were calculated.

Coincubation of Ru Complexes with Formate. Cell viability assays of complexes 1-4 were carried out with A2780 ovarian cancer cells with sodium formate. These experiments were performed with the following modifications: a fixed concentration of each Ru complex equal to $1 / 3 \times$ $\mathrm{IC}_{50}$ was used in coadministration with three different concentrations of sodium formate $(0.5,1.0$, and $2.0 \mathrm{mM}$ ). Drug stock solutions (ca. 100 $\mu \mathrm{M}$ ) were prepared as described for in vitro growth inhibition assays and then further diluted with media until working concentrations were achieved. Separately, a stock solution of sodium formate was prepared in saline. The complex and formate solutions were added to each well independently within $5 \mathrm{~min}$ of each other. All other experimental conditions were kept unchanged (drug exposure, cell recovery time, and end point assay used). The standard deviations were calculated.

\section{ASSOCIATED CONTENT}

\section{S Supporting Information}

The Supporting Information is available free of charge on the ACS Publications website at DOI: 10.1021/acs.organomet.8b00132.

Tables giving crystallographic data, induction of ROS and superoxide determined by flow cytometry, cell membrane integrity, and viability of A2780 ovarian cancer cells exposed to formate and complexes 1-4 and figures giving the determination of $\mathrm{p} K_{\mathrm{a}}$ of aqua complex $\mathbf{2 a}$ and reaction with 9-EtG, reaction of $\mathbf{2 a}$ with various mol equiv of GSH monitored by NMR and by HPLC, $2 \mathrm{D}$ COSY ${ }^{1} \mathrm{H}$ NMR spectrum for reaction of complex 2 with GSH, dependence of release of free sulfonylethylenediame ligand on time, and interaction of complexes with bacterial plasmid DNA (PDF)

\section{Accession Codes}

CCDC 1823316-1823319 contain the supplementary crystallographic data for this paper. These data can be obtained free of charge via www.ccdc.cam.ac.uk/data_request/cif, or by emailing data_request@ccdc.cam.ac.uk, or by contacting The Cambridge Crystallographic Data Centre, 12 Union Road, Cambridge CB2 1EZ, UK; fax: +44 1223336033.

\section{AUTHOR INFORMATION}

\section{Corresponding Author}

*E-mail for P.J.S.: p.j.sadler@warwick.ac.uk.

ORCID

Jana Kasparkova: 0000-0002-5279-5381

Martin Wills: 0000-0002-1646-2379

Viktor Brabec: 0000-0002-8233-1393

Peter J. Sadler: 0000-0001-9160-1941

Notes

The authors declare no competing financial interest.

\section{ACKNOWLEDGMENTS}

We thank the ERC (grant no. 247450) and EPSRC (grant no. EP/F034210/1), the China Scholarship Council (CSC) for a scholarship for F.C., and Bruker Daltonics and Warwick Collaborative Postgraduate Research Scholarship (WCPRS) for funding for J.P.C.C. This work was also supported by the Czech Science Foundation (Grant 17-09436S). We also thank Dr. Ivan Prokes, Dr. Lijiang Song, and Mr. Philip Aston (University of Warwick) for assistance with NMR and MS measurements, and Hannah Bridgewater for help with cell culture. 


\section{REFERENCES}

(1) Rosenberg, B.; Camp, L. V.; Krigas, T. Nature 1965, 205, 698-699.

(2) Bugarcic, T.; Habtemariam, A.; Deeth, R. J.; Fabbiani, F. P. A.; Parsons, S.; Sadler, P. J. Inorg. Chem. 2009, 48, 9444-9453.

(3) Castonguay, A.; Doucet, C.; Juhas, M.; Maysinger, D. J. Med. Chem. 2012, 55, 8799-8806.

(4) Aman, F.; Hanif, M.; Siddiqui, W. A.; Ashraf, A.; Filak, L. K.; Reynisson, J.; Söhnel, T.; Jamieson, S. M. F.; Hartinger, C. G. Organometallics 2014, 33, 5546-5553.

(5) Barry, N. P. E.; Sadler, P. J. Chem. Soc. Rev. 2012, 41, 3264-3279.

(6) Mukhopadhyay, S.; Gupta, R. K.; Paitandi, R. P.; Rana, N. K.; Sharma, G.; Koch, B.; Rana, L. K.; Hundal, M. S.; Pandey, D. S. Organometallics 2015, 34, 4491-4506.

(7) Han, S. H.; Kim, S.; De, U.; Mishra, N. K.; Park, J.; Sharma, S.; Kwak, J. H.; Han, S.; Kim, H. S.; Kim, I. S. J. Org. Chem. 2016, 81, 12416-12425.

(8) Gras, M.; Therrien, B.; Süss-Fink, G.; Casini, A.; Edafe, F.; Dyson, P. J. J. Organomet. Chem. 2010, 695, 1119-1125.

(9) Fu, Y.; Romero, M. J.; Habtemariam, A.; Snowden, M. E.; Song, L.; Clarkson, G. J.; Qamar, B.; Pizarro, A. M.; Unwin, P. R.; Sadler, P. J. Chem. Sci. 2012, 3, 2485-2494.

(10) Suntharalingam, K.; Johnstone, T. C.; Bruno, P. M.; Lin, W.; Hemann, M. T.; Lippard, S. J. J. Am. Chem. Soc. 2013, 135, 1406014063.

(11) Fu, Y.; Habtemariam, A.; Pizarro, A. M.; van Rijt, S. H.; Healey, D. J.; Cooper, P. A.; Shnyder, S. D.; Clarkson, G. J.; Sadler, P. J. J. Med. Chem. 2010, 53, 8192-8196.

(12) Almodares, Z.; Lucas, S. J.; Crossley, B. D.; Basri, A. M.; Pask, C. M.; Hebden, A. J.; Phillips, R. M.; McGowan, P. C. Inorg. Chem. 2014, 53, 727-736.

(13) Liu, Z.; Romero-Canelón, I.; Qamar, B.; Hearn, J. M.; Habtemariam, A.; Barry, N. P. E.; Pizarro, A. M.; Clarkson, G. J.; Sadler, P. J. Angew. Chem., Int. Ed. 2014, 53, 3941-3946.

(14) Divsalar, A.; Bagheri, M. J.; Saboury, A. A.; Mansoori-Torshizi, H.; Amani, M. J. Phys. Chem. B 2009, 113, 14035-14042.

(15) Lease, N.; Vasilevski, V.; Carreira, M.; de Almeida, A.; Sanaú, M.; Hirva, P.; Casini, A.; Contel, M. J. Med. Chem. 2013, 56, 5806-5818.

(16) Reddy, E. R.; Trivedi, R.; Sarma, A. V. S.; Sridhar, B.; Anantaraju, H. S.; Sriram, D.; Yogeeswarid, P.; Nagesh, N. Dalton Trans. 2015, 44, 17600-17616

(17) Spencer, J.; Rathnam, R. P.; Motukuri, M.; Kotha, A. K.; Richardson, S. C. W.; Hazrati, A.; Hartley, J. A.; Malec, L.; Hursthouse, M. B. Dalton Trans. 2009, 22, 4299-4303.

(18) Aird, R. E.; Cummings, J.; Ritchie, A. A.; Muir, M.; Morris, R. E.; Chen, H.; Sadler, P. J.; Jodrell, D. I. Br. J. Cancer 2002, 86, 1652-1657.

(19) Xue, S. S.; Tan, C. P.; Chen, M. H.; Cao, J. J.; Zhang, D. Y.; Ye, R

R.; Ji, L. N.; Mao, Z. W. Chem. Commun. 2017, 53, 842-845.

(20) Gianferrara, T.; Bergamo, A.; Bratsos, I.; Milani, B.; Spagnul, C.; Sava, G.; Alessio, E. J. Med. Chem. 2010, 53, 4678-4690.

(21) Bergamo, A.; Gava, B.; Alessio, E.; Mestroni, G.; Serli, B.; Cocchietto, M.; Zorzet, S.; Sava, G. Int. J. Oncol. 2002, 21, 1331-1338.

(22) Kapitza, S.; Pongratz, M.; Jakupec, M. A.; Heffeter, P.; Berger, W.; Lackinger, L.; Keppler, B. K.; Marian, B. J. J. Cancer Res. Clin. Oncol. 2005, 131, 101-110.

(23) Ang, W. H.; Daldini, E.; Scolaro, C.; Scopelliti, R.; JuilleratJeannerat, L.; Dyson, P. J. Inorg. Chem. 2006, 45, 9006-9013.

(24) Reisner, E.; Arion, V. B.; Eichinger, A.; Kandler, N.; Giester, G.; Pombeiro, A. J. L.; Keppler, B. K. Inorg. Chem. 2005, 44, 6704-6716.

(25) Pelletier, F.; Comte, V.; Massard, A.; Wenzel, M.; Toulot, S.; Richard, P.; Pquet, M.; Gendre, P. L.; Zava, O.; Edafe, F.; Casini, A.; Dyson, P. J. J. Med. Chem. 2010, 53, 6923-6933.

(26) Nowak-Sliwinska, P.; Beijnum, J. R.; Casini, A.; Nazarov, A. A.; Wagnieres, G.; van den Bergh, H.; Dyson, P. J.; Griffioen, A. W. J. Med. Chem. 2011, 54, 3895-3902.

(27) Chen, H.; Parkinson, J. A.; Parsons, S.; Coxall, R. A.; Gould, R. O.; Sadler, P. J. J. Am. Chem. Soc. 2002, 124, 3064-3082.

(28) Wang, F.; Xu, J.; Habtemariam, A.; Bella, J.; Sadler, P. J. J. Am. Chem. Soc. 2005, 127, 17734-17743.
(29) Barrett, S. M.; Pitman, C. L.; Walden, A. G.; Miller, A. J. M. J. Am. Chem. Soc. 2014, 136, 14718-14721.

(30) Carrión, M. C.; Sepúlveda, F.; Jalón, F. A.; Manzano, B. R.; Rodríguez, A. M. Organometallics 2009, 28, 3822-3833.

(31) Maenaka, Y.; Suenobu, T.; Fukuzumi, S. J. Am. Chem. Soc. 2012, 134, 9417-9427.

(32) Wolfson, A.; Dlugy, C.; Shotland, Y.; Tavor, D. Tetrahedron Lett. 2009, 50, 5951-5953.

(33) Fujii, A.; Hashiguchi, S.; Uematsu, N.; Ikariya, T.; Noyori, R. J. Am. Chem. Soc. 1996, 118, 2521-2522.

(34) Hashiguchi, S.; Fujii, A.; Takehara, J.; Ikariya, T.; Noyori, R. J. Am. Chem. Soc. 1995, 117, 7562-7563.

(35) Yan, Y.; Melchart, M.; Habtemariam, A.; Peacock, A. F. A.; Sadler, P. J. JBIC, J. Biol. Inorg. Chem. 2006, 11, 483-488.

(36) Soldevila-Barreda, J. J.; Bruijnincx, P. C. A.; Habtemariam, A.; Clarkson, G. J.; Deeth, R. J.; Sadler, P. J. Organometallics 2012, 31, 5958-5967.

(37) Soldevila-Barreda, J. J.; Romero-Canelón, I.; Habtemariam, A.; Sadler, P. J. Nat. Commun. 2015, 6, 6582.

(38) Hayes, A. M.; Morris, D. J.; Clarkson, G. J.; Wills, M. J. Am. Chem. Soc. 2005, 127, 7318-7319.

(39) Martins, J. E. D.; Clarkson, G. J.; Wills, M. Org. Lett. 2009, 11, $847-850$

(40) Hannedouche, J.; Clarkson, G. J.; Wills, M. J. Am. Chem. Soc. 2004, 126, 986-987.

(41) Soni, R.; Cheung, F. K.; Clarkson, G. C.; Martins, J. E. D.; Graham, M. A.; Wills, M. Org. Biomol. Chem. 2011, 9, 3290-3294.

(42) Fu, Y.; Sanchez-Cano, C.; Soni, R.; Romero-Canelón, I.; Hearn, J. M.; Liu, Z.; Wills, M.; Sadler, P. J. Dalton Trans. 2016, 45, 8367-8378.

(43) Jolley, K. E.; Zanotti-Gerosa, A.; Hancock, F.; Dyke, A.; Grainger, D. M.; Medlock, J. A.; Nedden, H. G.; LePaih, J. J. M.; Roseblade, S. J.; Seger, A.; Sivakumar, V.; Prokes, I.; Morris, D. J.; Wills, M. Adv. Synth. Catal. 2012, 354, 2545-2555.

(44) Habtemariam, A.; Melchart, M.; Fernández, R.; Parsons, S.; Oswald, I. D. H.; Parkin, A.; Fabbiani, F. P. A.; Davidson, J. E.; Dawson, A.; Aird, R. E.; Jodrell, D. I.; Sadler, P. J. J. Med. Chem. 2006, 49, 68586868.

(45) Morris, R. E.; Aird, R. E.; Murdoch, P. S.; Chen, H.; Cummings, J.; Hughes, N. D.; Parsons, S.; Parkin, A.; Boyd, G.; Jodrell, D. I.; Sadler, P. J. J. Med. Chem. 2001, 44, 3616-3621.

(46) Cheung, F. K.; Clarke, A. J.; Clarkson, G. J.; Fox, D. J.; Graham, M. A.; Lin, C.; Crivilléa, A. L.; Wills, M. Dalton Trans. 2010, 39, 1395-1402.

(47) Ying, W. Antioxid. Redox Signaling 2008, 10, 179-206.

(48) McSkimming, A.; Colbran, S. B. Chem. Soc. Rev. 2013, 42, 54395488.

(49) Steckhan, E.; Herrmann, S.; Ruppert, R.; Dietz, E.; Frede, M.; Spika, E. Organometallics 1991, 10, 1568-1577.

(50) Westerhausen, V. D.; Herrmann, S.; Hummel, W.; Steckhan, E. Angew. Chem., Int. Ed. Engl. 1992, 31, 1529-1531.

(51) Lo, H. C.; Leiva, C.; Buriez, O.; Kerr, J. B.; Olmstead, M. M.; Fish, R. H. Inorg. Chem. 2001, 40, 6705-6716.

(52) Zhou, H.; Li, Z.; Wang, Z.; Wang, T.; Xu, L.; He, Y.; Fan, Q.; Pan, J.; Gu, L.; Chan, A. S. C. Angew. Chem., Int. Ed. 2008, 47, 8464-8467.

(53) Wang, C.; Li, C.; Wu, X.; Pettman, A.; Xiao, J. Angew. Chem., Int. Ed. 2009, 48, 6524-6528.

(54) Lo, H. C.; Buriez, O.; Kerr, J. B.; Fish, R. H. Angew. Chem., Int. Ed. 1999, 38, 1429-1432.

(55) Lo, H. C.; Fish, R. H. Angew. Chem., Int. Ed. 2002, 41, 478-481.

(56) Wu, X.; Liu, J.; Li, X.; Zanotti-Gerosa, A.; Hancock, F.; Vinci, D.; Ruan, J.; Xiao, J. Angew. Chem., Int. Ed. 2006, 45, 6718-6722.

(57) Tan, J.; Tang, W.; Sun, Y.; Jiang, Z.; Chen, F.; Xu, L.; Fan, Q.; Xiao, J. Tetrahedron 2011, 67, 6206-6213.

(58) Garai-Ibabe, G.; Saa, L.; Pavlov, V. Anal. Chem. 2013, 85, 55425546.

(59) Mu, C.; Chang, S. W.; Prosser, K. E.; Leung, A. W. Y.; Santacruz, S.; Jang, T.; Thompson, J. R.; Yapp, D. T. T.; Warren, J. J.; Bally, M. B.; Beischlag, T. V.; Walsby, C. J. Inorg. Chem. 2016, 55, 177-190.

(60) Kartalou, M.; Essigmann, J. M. Mutat. Res., Fundam. Mol. Mech. Mutagen. 2001, 478, 23-43. 
(61) Belani, C. P. Semin. Oncol. 2004, 31, 25-33.

(62) Coley, H. M.; Sarju, J.; Wagner, G. J. Med. Chem. 2008, 51, 135141.

(63) Bugarcic, T.; Nováková, O.; Halámiková, A.; Zerzánková, L.; Vrána, O.; Kašpárková, J.; Habtemariam, A.; Parsons, S.; Sadler, P. J.; Brabec, V. J. Med. Chem. 2008, 51, 5310-5319.

(64) Tan, C.; Wu, S.; Lai, S.; Wang, M.; Chen, Y.; Zhou, L.; Zhu, Y.; Lian, W.; Peng, W.; Ji, L.; Xu, A. Dalton Trans. 2011, 40, 8611-8621.

(65) Romero-Canelón, I.; Salassa, L.; Sadler, P. J. J. Med. Chem. 2013, 56, 1291-1300.

(66) Liu, H.; Li, Y.; Raisch, K. P. Anti-Cancer Drugs 2010, 21, 841-849.

(67) Demidenko, Z. N.; Kalurupalle, S.; Hanko, C.; Lim, C.; Broude, E.; Blagosklonny, M. V. Oncogene 2008, 27, 4402-4410.

(68) Karsenti, E.; Vernos, I. Science 2001, 294, 543-547.

(69) D’Autreaux, B.; Toledano, M. B. Nat. Rev. Mol. Cell Biol. 2007, 8, $813-824$.

(70) Dharmaraja, A. T. J. Med. Chem. 2017, 60, 3221-3240.

(71) Dolomanov, O. V.; Bourhis, L. J.; Gildea, R. J.; Howard, J. A. K.; Puschmann, H. J. Appl. Crystallogr. 2009, 42, 339-341.

(72) Sheldrick, G. M. Acta Crystallogr., Sect. A: Found. Adv. 2015, 71, 3-8.

(73) Sheldrick, G. M. Acta Crystallogr., Sect. A: Found. Crystallogr. 2008, 64, 112-122. 